فصلنامdعلمى - يُزوهشىرفاهاجتماعى،سال هجدهم،بهار 9V، شماره TV

Social Welfare Quarterly, Vol 18, Spring 2018, No 68

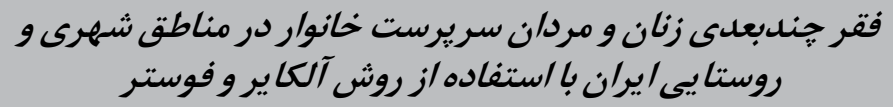

\title{
Comparing Multidimensional Poverty of Female and Men Headed Households in Urban and Rural areas in Iran by Alkire-Foster Method
}

Mohammad hasan fotros ${ }^{1}$, sudeh ghodsi ${ }^{2}$

Introduction: Poverty reduction is one of the most important economic and social goals of politicians and programmers in different societies. Women are more exposed to poverty and gender discrimination in comparison with men. This is because women do not have necessary capabilities and facilities for empowerment and poverty reduction. Hence, for anti-poverty programs in the country, policymakers need, in the first step, to measure poverty especially in female-headed households.

In this study, after measuring the multidimensional poverty index in male and female headed households, it is attempted to analyze the poverty status of female headed household and to determine the factors affecting their poverty.

Method: In this study, the multidimensional poverty index is calculated for men and women-headed households based on Alkire and Foster method in three dimensions education, health and standard

1. Ph.D. in Economic,

$<$ fotros@basu.ac.ir>

2. Ph.D. in Economic

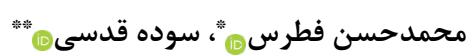

مقدمه: كاهش فقر يكى /ز مهمترين /هداف

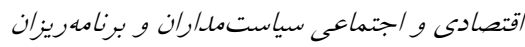

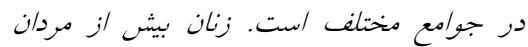
در معرض فقر و تبعيض جنسيتى قرار دارند.

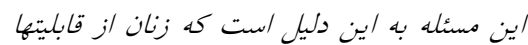

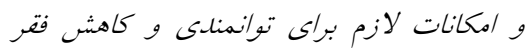

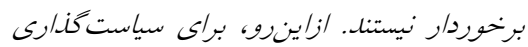

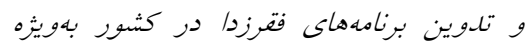

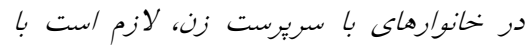

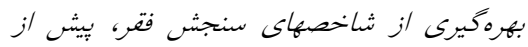

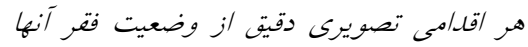

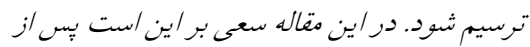

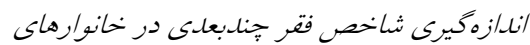

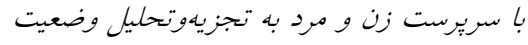

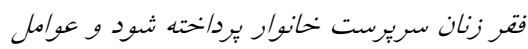

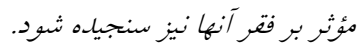

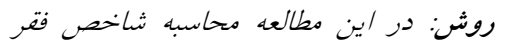

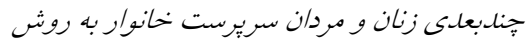

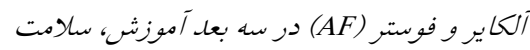

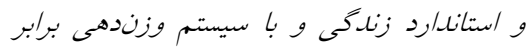

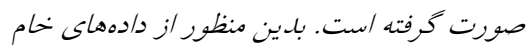

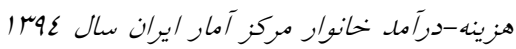

* دكتر اقتصاد، دانشگاه بوعلى سينا، (نويسنده مسئول) <fotros@basu.ac.ir>

$$
\text { *\%: دكتر اقتصاد، دانشگاه بوعلى سينا }
$$


of living with an equal weighting system. In this study, household's income expenditure raw data published by the Statistical Center of Iran in 2015 were used. Furthermore, the factors that affect poor female- headed households was estimated using a logit regression model.

Findings: The results showed that intensity and incidence of poverty among female-headed households is higher than men-headed households in both urban and rural areas. There is significant differences between female-headed households' MPI in urban areas by 0.0942 and male-headed households' MPI by 0.0516 . Also, female-headed households' MPI is equal to 0.067 and men-headed households' MPI is equal to 0.0364 in rural areas. The highest female-headed households' deprivation is respectively in sanitation, years of schooling and health insurance in urban areas and the highest deprivation in rural areas is respectively in sanitation, years of education and building structures. Logit regression model also showed that being older, unemployed, a housewife, and married female-heads of households increase the probability of being poor

Discussion: Based on the findings,

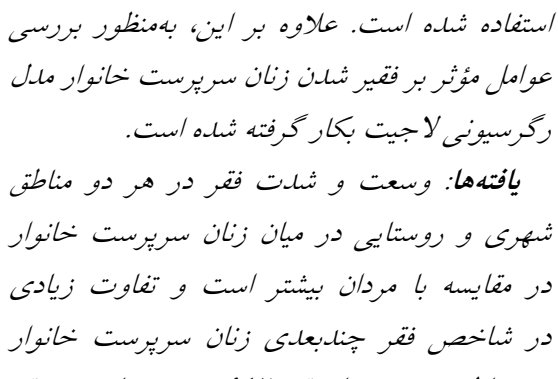

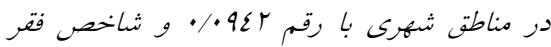
جنابعلى مردان سريرست خلانوار با رقم

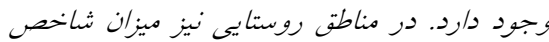

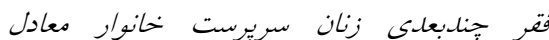

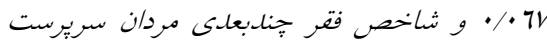

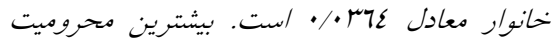

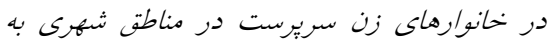

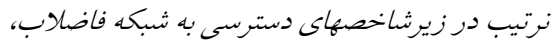

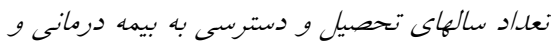

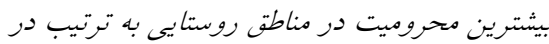
زيرشاخصهاى دسترسى به شبكه فاضلاب، تعلداد

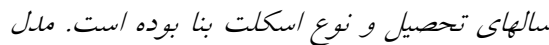

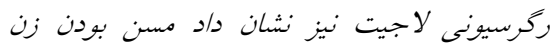

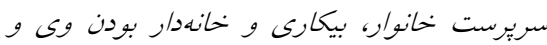

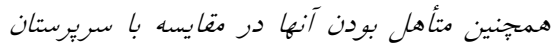

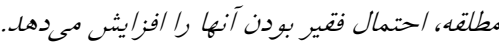

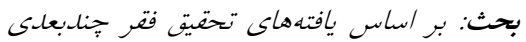

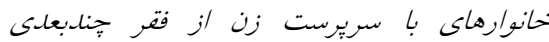

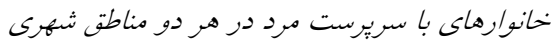

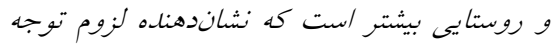

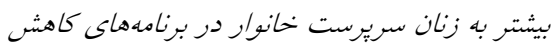

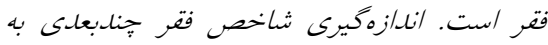

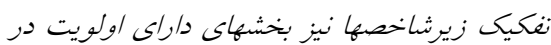


the multidimensional poverty of female-headed households is more than the multidimensional poverty of male-headed households in both urban and rural areas indicating that female households need more attention in poverty reduction programs. Measuring the multidimensional poverty index by indicators also highlights priority sectors in poverty reduction programs. The Logit regression model also showed that years of schooling is very important because the empowerment of female- headed households in education empowers them to find a job and earn money.

Keywords: Alkire and Foster method, Female-headed household, Female poverty, Multidimensional poverty

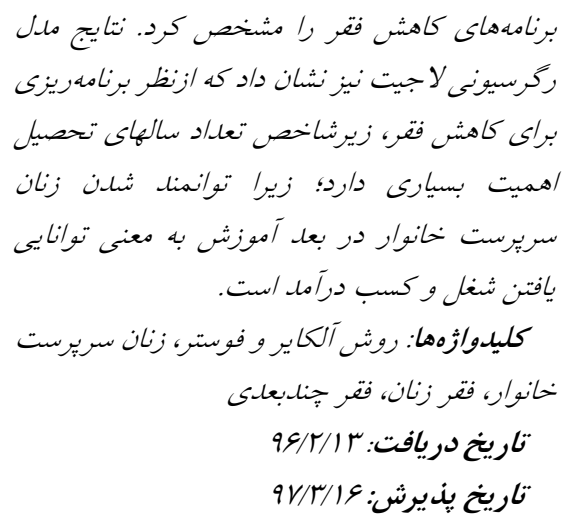

مقدمه

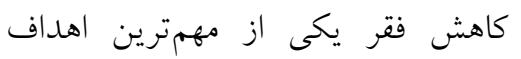

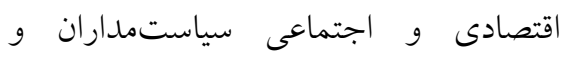

برنامهريزان در جوامع مختلف است. از طرفى ازجمله تغييرات اجتماعى و جمعيتى كسترده كه ايران در سالهاى كذشته تجربه كرده، تغيير در تعداد زنان سريرست خانوار بوده است. اين مسئله، زنان و خانو ادهاى آنها را در كانون توجه قرار داده است. زنان از قابليتهاى لازم براى توانمند شدن و هم:جنين امكانات كافى براى كاهش فقر برخوردار نبوده و بنابر اين بيش از مردان در معرض فقر و تبعيض جنسيتى قرار دارند. وجود موانع و محدوديتهاى فراوان بر سر راه تغيير و تحول بايخاه اقتصادى و اجتماعى زنان متأثر از عوامل فرهنكى و حقوقى، هركونه تلاشى را براى از بين بردن فقر آنها با مشكل مواجه

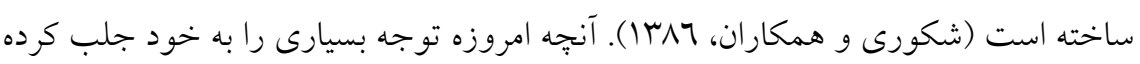




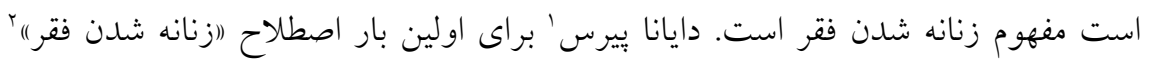

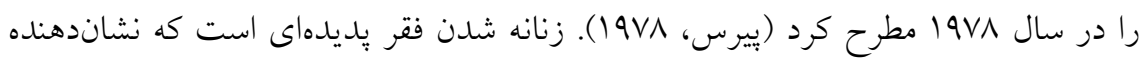
درصد نامتناسب زنان فقير در جهان است.

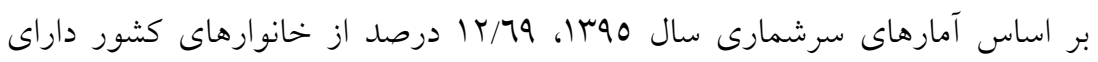
سريرست زن هستند كه اين رقم در مقايسه با سالهاى قبل افزايش يافته است. در بين زنان

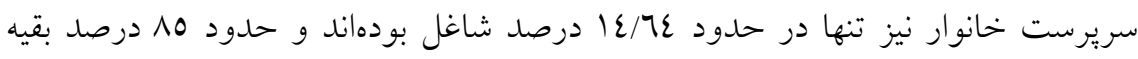

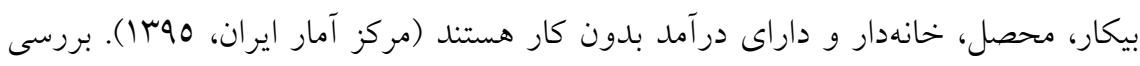

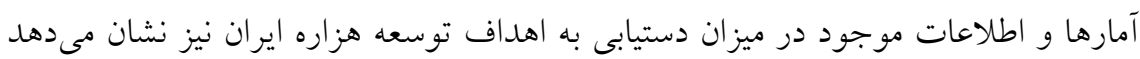

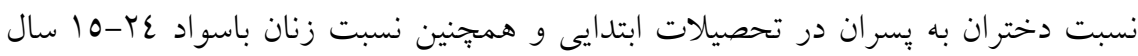

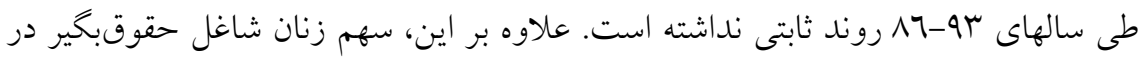

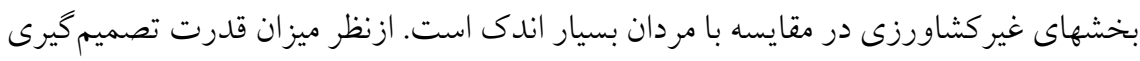

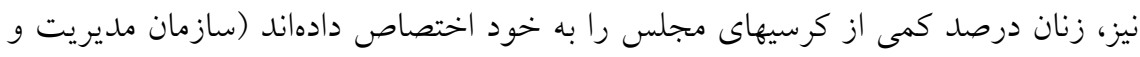

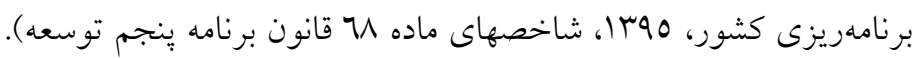

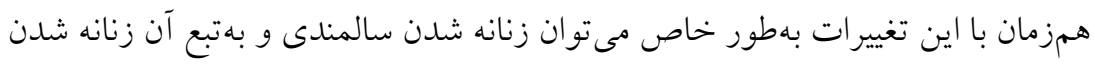

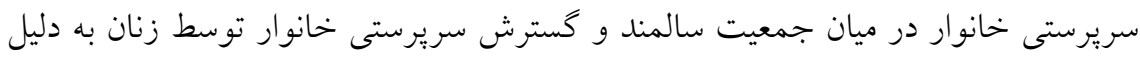
فوت همسر، عدم ازدواج زنان و مجرد باقى ماندن آنها يا افزايش ميزان طلاق ران را مشاهده

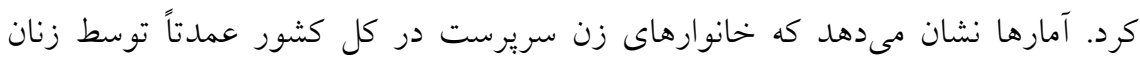

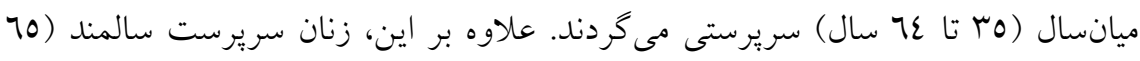

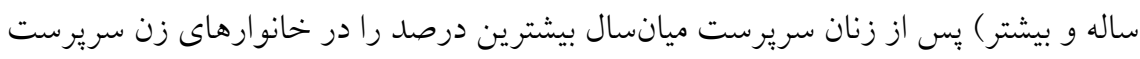

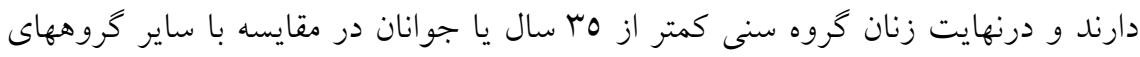

1. Diana Pearce

2. feminization of poverty 
سنى، در رتبه بعدى قرار دارند. ترتيبات زندگى زنان سريرست خانوار نيز نشان مىدهد كه

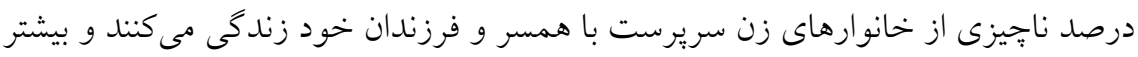

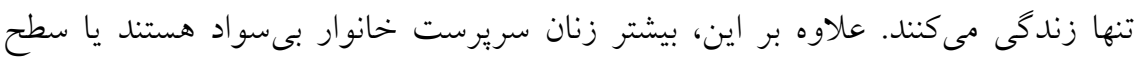

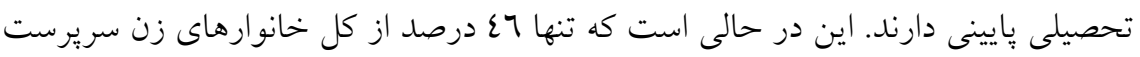

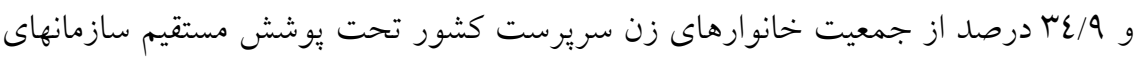
حمايتى عمده ازجمله كميته امداد امام، سازمان بهزيستى، ستاد تو انمندسازى و... قرار دارند. بررسى ويز گيهاى اقتصادى خانو ارهاى زن سريرست در مقايسه با خانوارهاى مرد سريرست

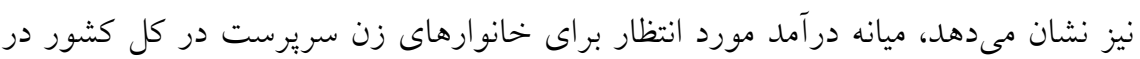

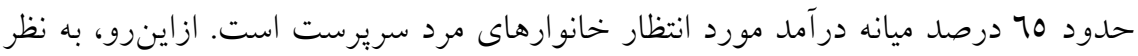

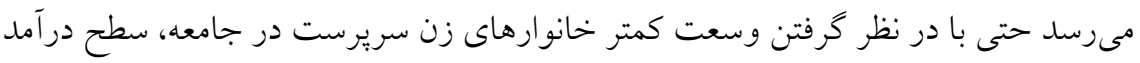
اين خانوارها كمتر از خانوارهاى مرد سريرست است. همخينين نسبت اشتغال سريرستان

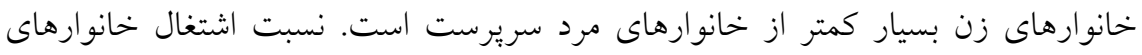
زن سريرست در كل كشور معادل \|/ • و در خانوارهاى مرد سريرست V0/• است. ازنظر

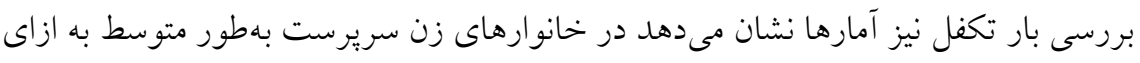

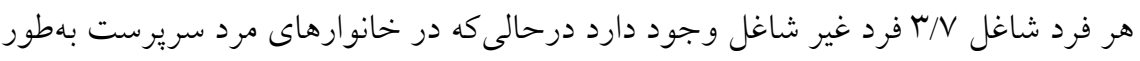

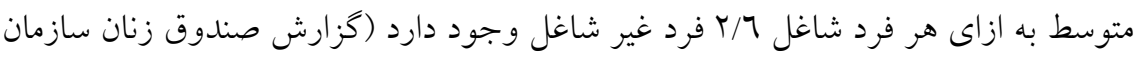

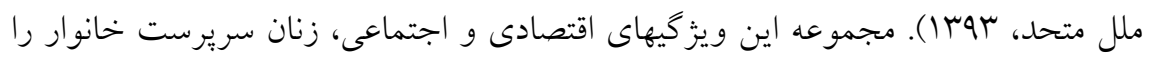

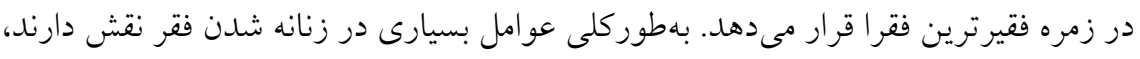

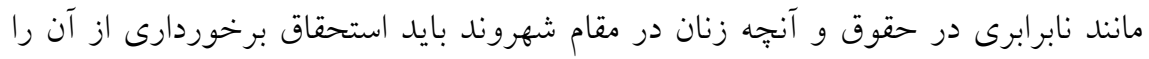
داشته باشند، نابرابرى در قابليتها به دليل نابرابرى در فرصتها و ييامدهاى نابرابر سياستهاى تعديل ساختارى، زنانه شدن بخش غيررسمى اقتصاد و محروميت زنان از امتيازات اشتغال

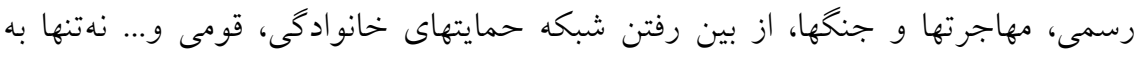


زنانه شدن فقر بلكه به بيوستن قشر خاصى از زنان يعنى (زنان سريرست خانوار) به كروه

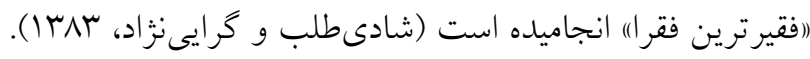
يرداختن به موضوع خانوارهاى زن سريرست و بررسى ويز كيهاى اين خانوارها و مقايسه

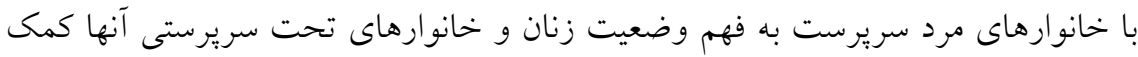
خواهد كرد؛ بنابراين، براى سياست كذارى و تدوين برنامههاى فقرزداى زنان سريرست

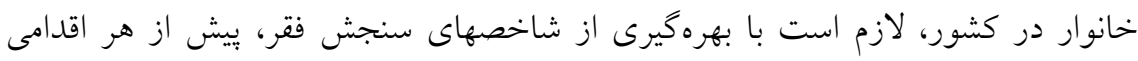
تصويرى دقيق از وضعيت فقر زنان سريرست خانوار در مقايسه با مردان ترسيم شود؛

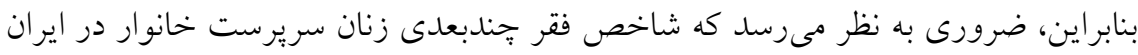

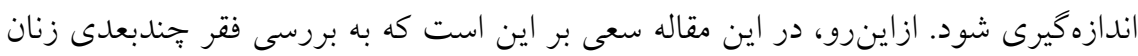

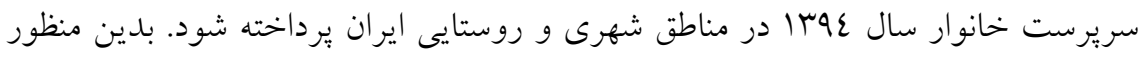

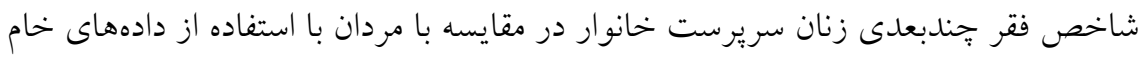

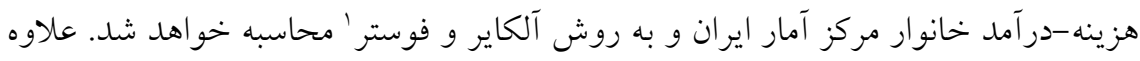

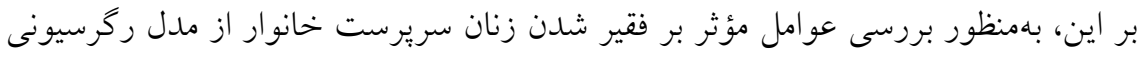

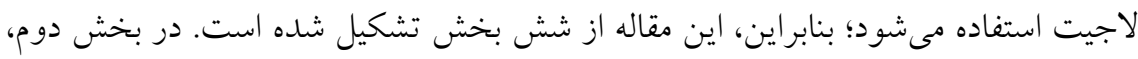

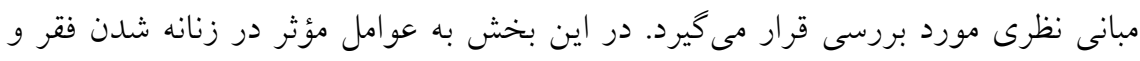

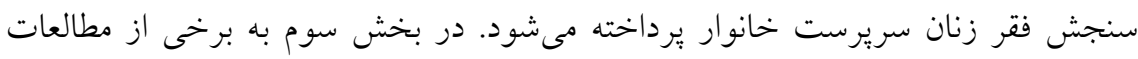
داخلى و خارجى انجام شده درزمينه فقر تندبعدى و همجينين فقر زنان اشارهاى خواهيم

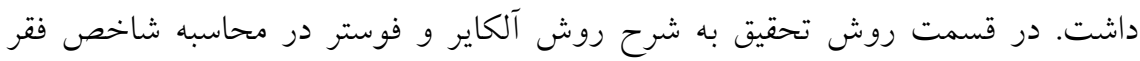
جندبعدى زنان سريرست خانوار و همجنين وسعت و شدت فقر يرداخته مىشود. علاوه بر اين، با استفاده از مدل لاجيت عوامل مؤثر در فقر هندبعدى زنان سريرست خانوار مورد بررسى قرار مى گيرد. درنهايت مقاله با ارائه نتايج تحقيق و جمع بندى به به بايان مىرسد.

1. Alkire and Foster 


\section{مبانى نظرى}

\section{1. إموامل مؤثر در زنانه شدن فقر}

نكته قابل توجه اين است كه مردان و زنان سريرست خانوار هر دو با فقر مواجه مىشوند

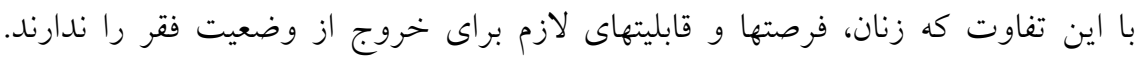

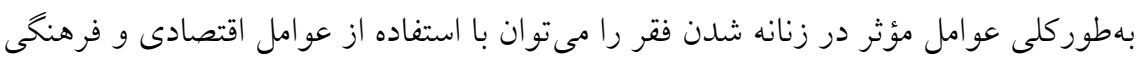

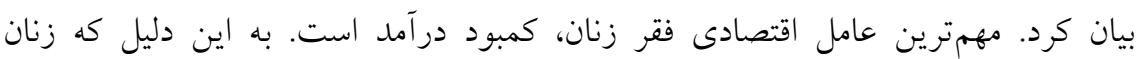

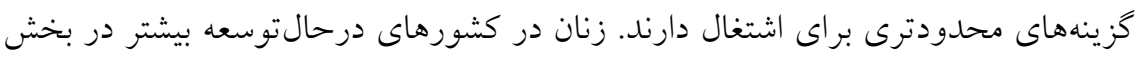

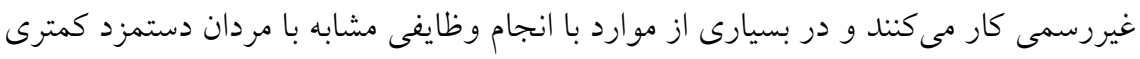

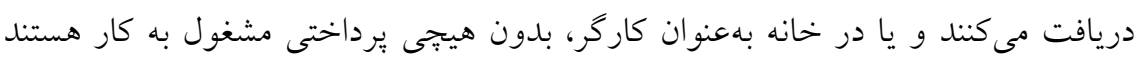

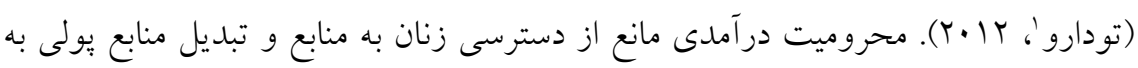

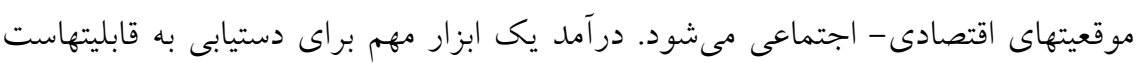

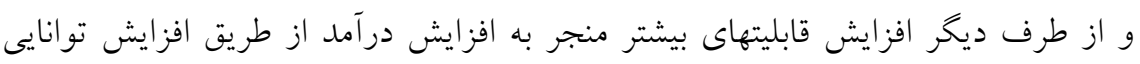

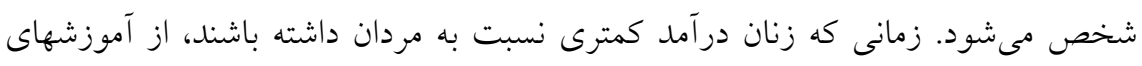

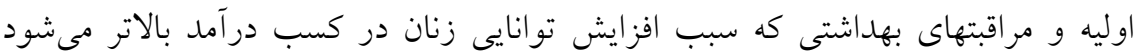

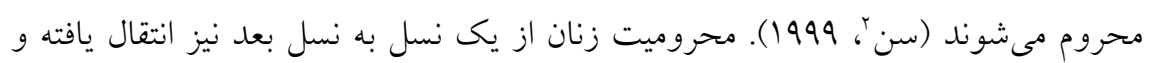

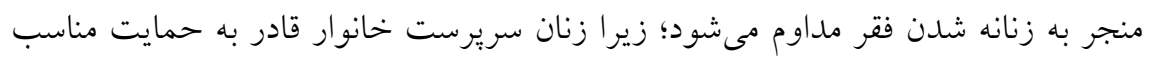

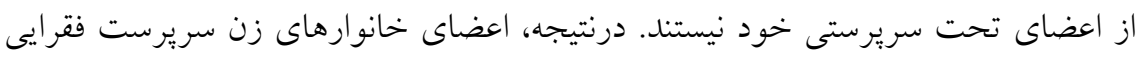

$$
\text { هستند كه در يك دايره بسته حركت مى كنند. }
$$

علاوه بر اين، زنانه شدن فقر درنتيجه محروميت از قابليتها و تبعيضهاى جنسيتى در برد جوامع مختلف است و شامل عدم حق انتخاب و نداشتن فرصتهايى مانند توانايى رهبرى

1. Todaro

2. Sen 
يكى زندگى طولانى و سالم و همجنين بهره بردن از حقوق انسانى مانند آزادى، حس احترام

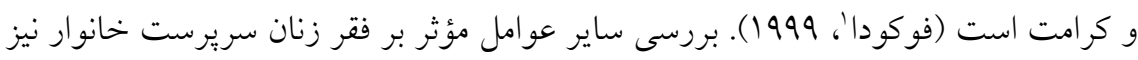

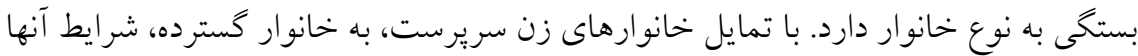
متفاوت خواهد بود؛ از يكسو، حمايتهاى اقوام و بستخان كه كمتر شامل حال خانوارهاى

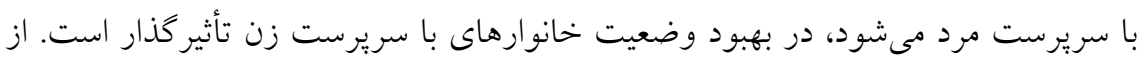

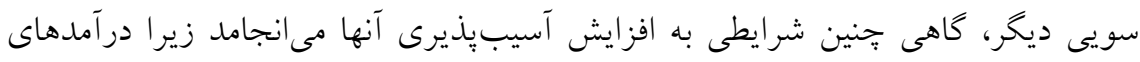

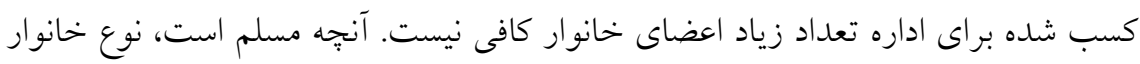
در فقير بودن يا نبودن خانوارهاى زن سريرست مؤثر است.

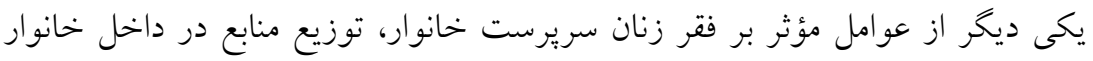

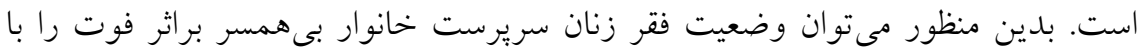

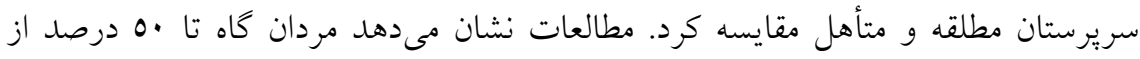

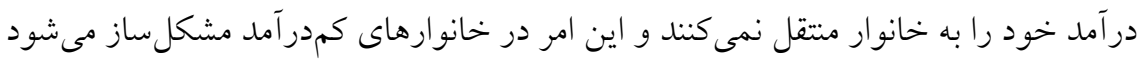

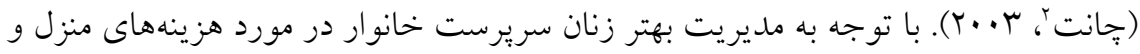

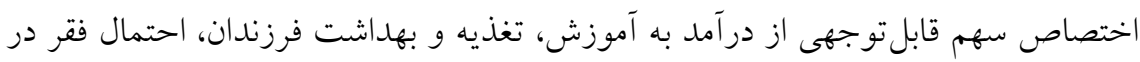
خانوارهاى زن سريرست مىتو اند بهاندازه خانوارهاى مرد سريرست باشد؛ بنابر اين حضور

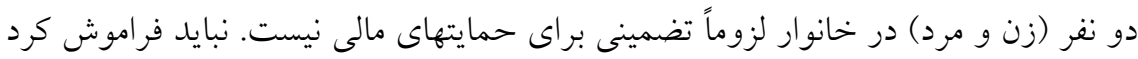

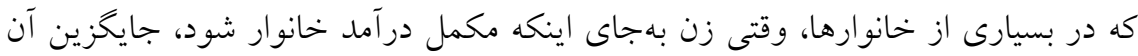

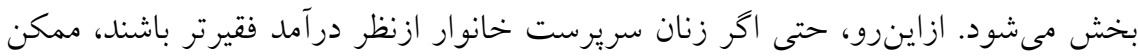

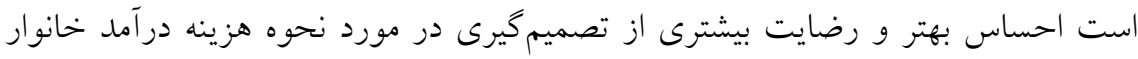

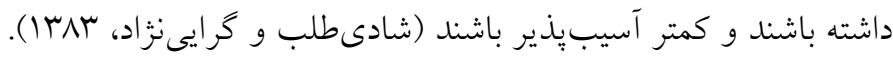

1. Fukuda

2. Chant 
زنان نقش مهمى در رشد و توسعه اقتصادى ايفا مى كند و علاوه بر نقش اقتصادى،

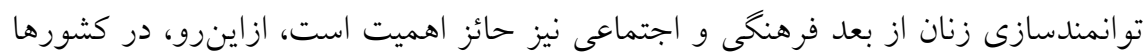
به تو انمندسازى زنان توجه ويزهاى مىشود.

\section{( T,Y,Y سنجش فقر زنان سريرست خانوار}

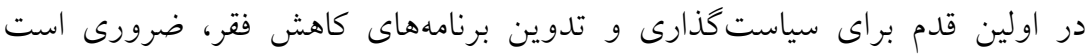

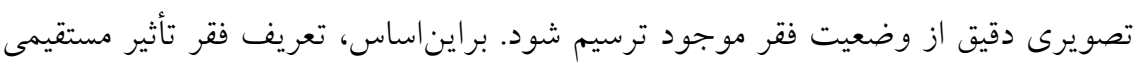

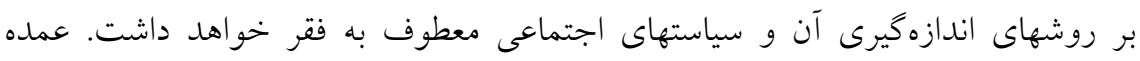

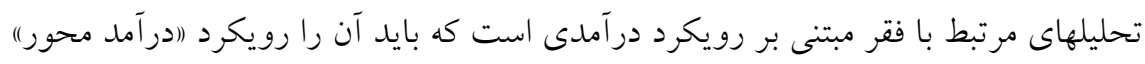

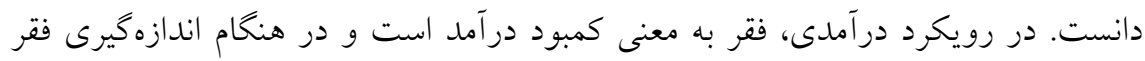

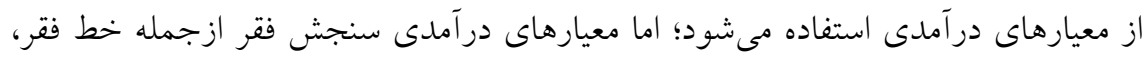

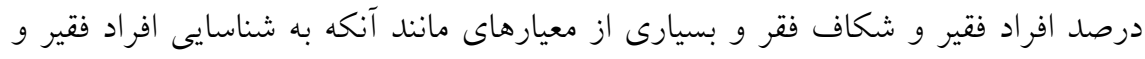

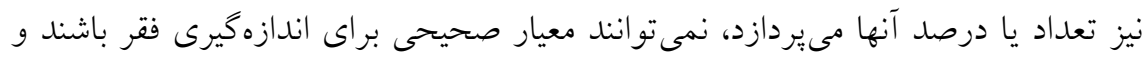

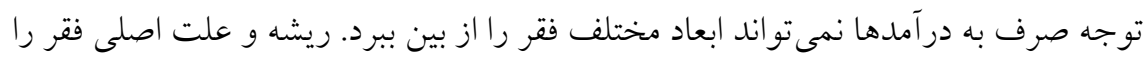

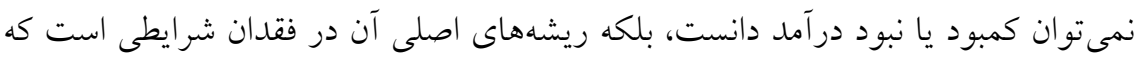

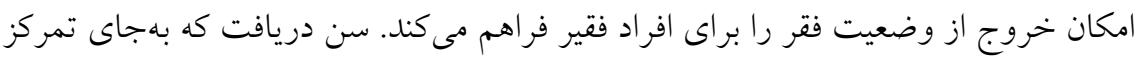

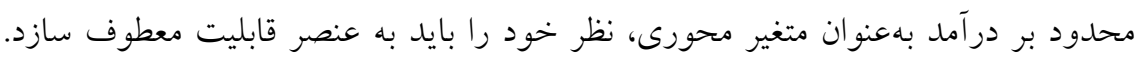

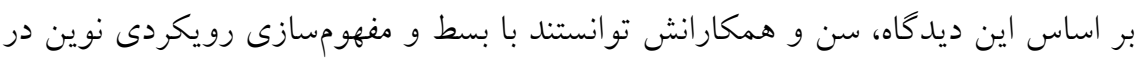

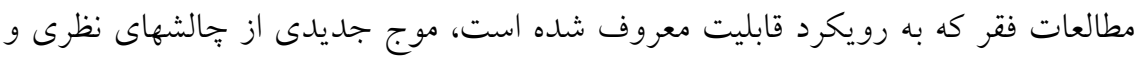

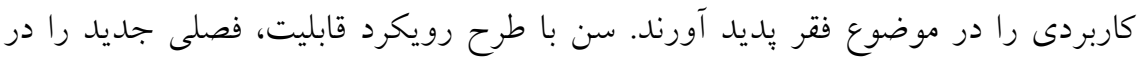

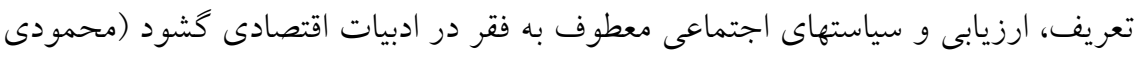

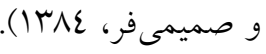


بر اساس آنجه كَفته شد، معيارهايى جون خط فقر، درصد افراد فقير و شكاف فقر و

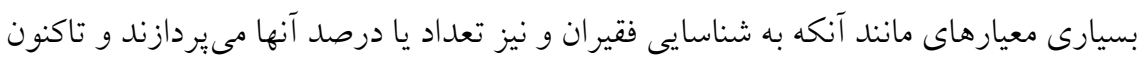

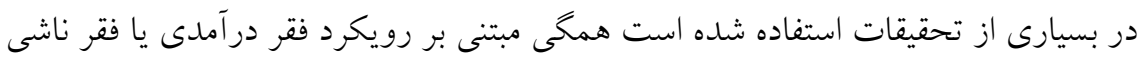

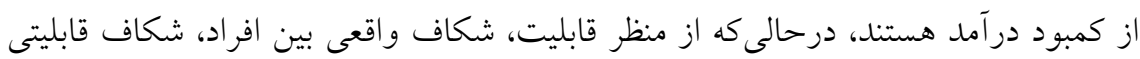

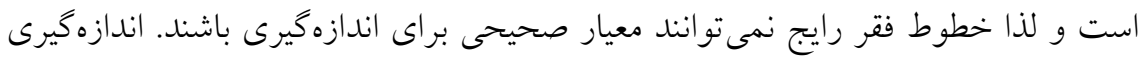

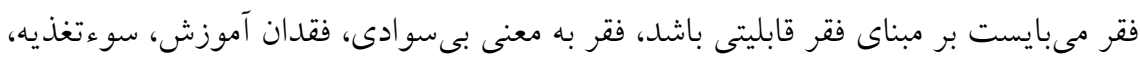

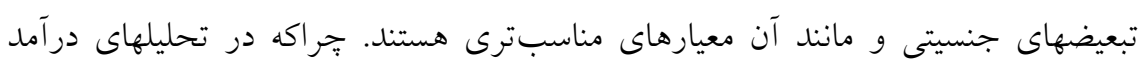

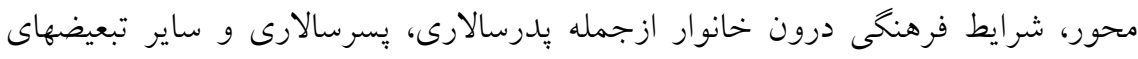

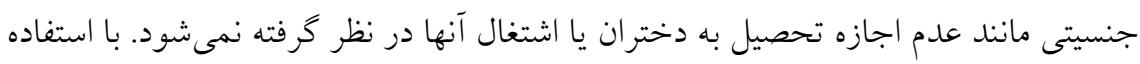

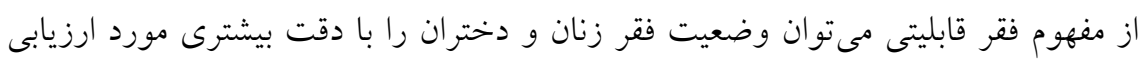

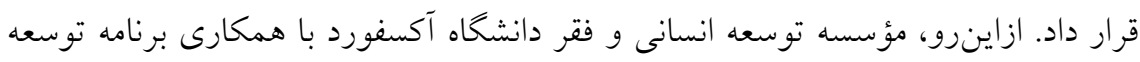

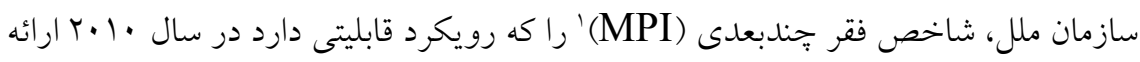

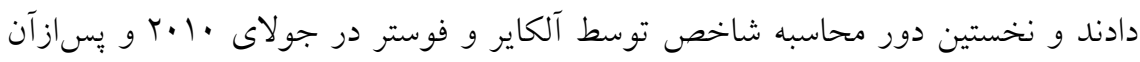

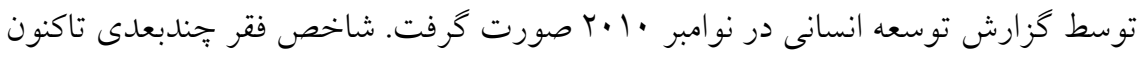

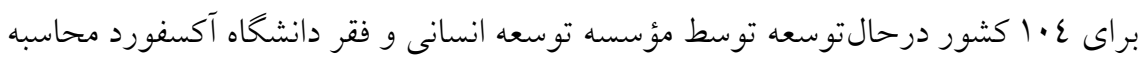
شده است. در هر سال نيز محاسبه شاخص كشورها از طريق معيارهايى كه بهبود مى يابند صورت مى گيرد.

هدف شاخص فقر جندبعدى، شناسايى ضعف امكانات اوليه براى افراد است كه فراهم

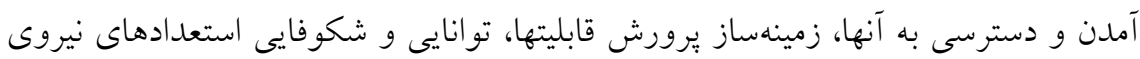

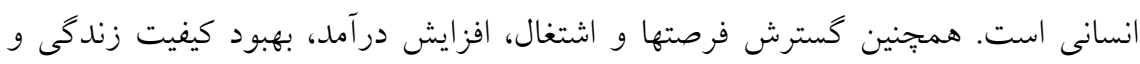
برخوردارى از زندگى سالم و خلاق در محيط زيستى بايدار، هدف نهايى توسعه بوده كه 
در سايه شناسايى وضعيت فقر بر اساس معيارهاى موجود ازجمله شاخص فقر جندبعدى ميسر است. ازآنجايى كه اين شاخص به بررسى فقر در وضعيتى مستقل از درآمدها مى يردازد،

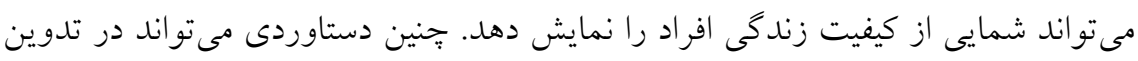

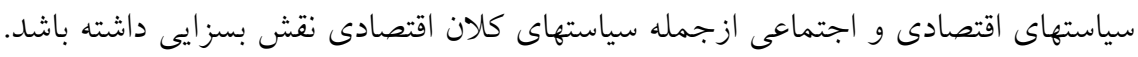

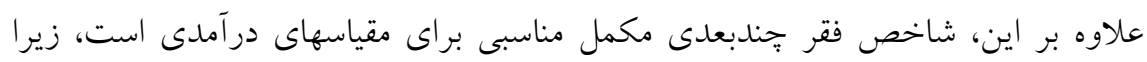

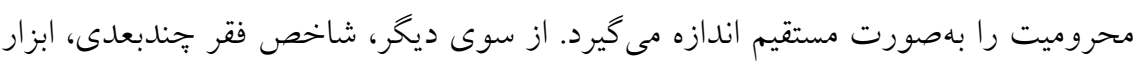

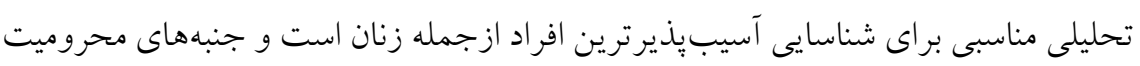

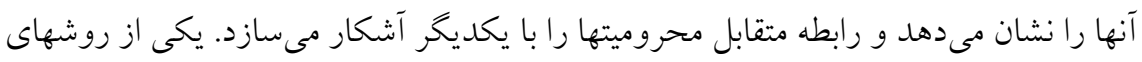

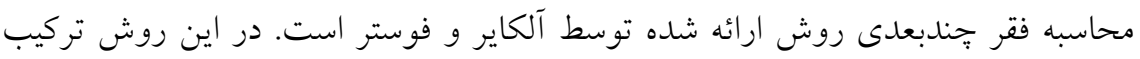

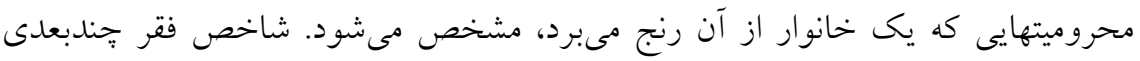

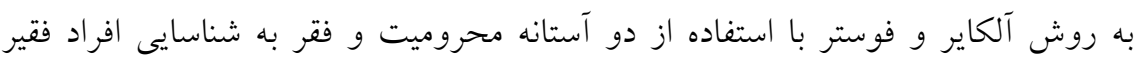

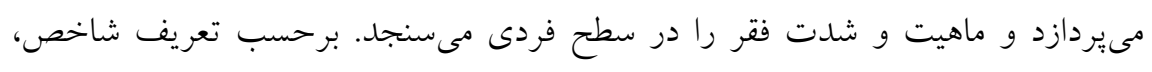

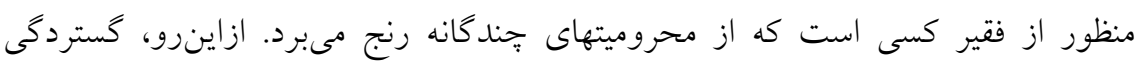

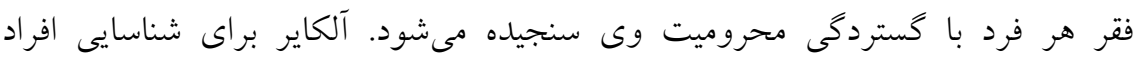

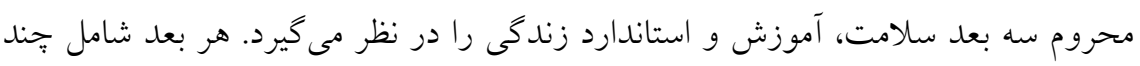
زيرشاخص است. هشت زيرشاخص از بين ده زيرشاخص مطابق با اهداف توسعه هز اره

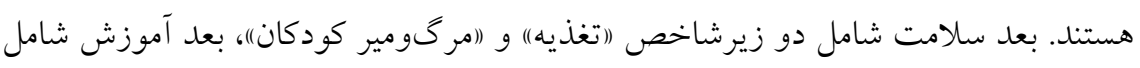

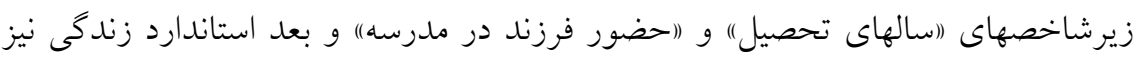

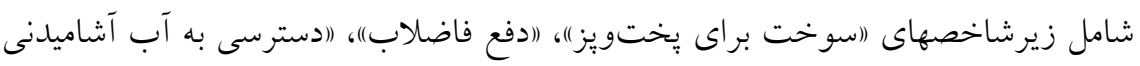

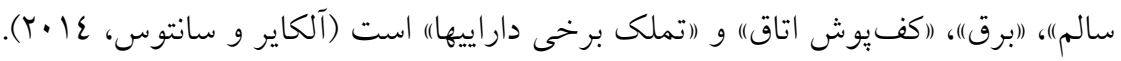




\section{يشينه تجربى}

در رابطه با اندازهگيرى فقر جندبعدى بهويزه به روش آلكاير و فوستر مطالعات مختلفى

صورت كرفته است كه در اين قسمت به برخى از مطالعات خارجى و داخلى بيرامون آن اشاره مىشود.

مهممترين مطالعه درزمينه سنجش فقر جنندبعدى، شاخص جديد برنامه عمران سازمان ملل متحد است كه بر اساس ديدگاه قابليت و با استفاده از روش آلكاير و فوستر، در گزارشهاى ساليانه توسعه انسانى، فقر را در كشورهاى مختلف ارائه مىدهد. اين شاخص براى اولين

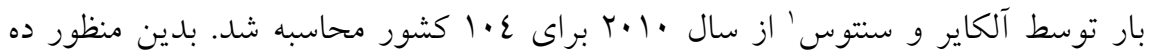
زيرشاخص در قالب سه بعد آموزش، سلامت و استاندارد زندگى در نظر گرفته شدند و از بين ع • ا كشور اطلاعات مربوط بهتمامى ابعاد در كال كشور موجود بوده است. نتايج نشان داد بيشترين فقر جندبعدى به ترتيب در جنوب آسيا با 9 •0 درصد و در آفريقاى زيرصحرا با رقم rV/7 درصد است. در كشورهايى مانند عراق، اكوادور، آلبانى، گواتمالا و آلبانى بيشترين محروميت در بعد آموزش و در كشورهايى مانند مجارستان، ازبكستان و لتونى بيشترين محروميت در بعد سلامت است. كشورهاى برو، مالاوى، سرىلانكا و بوليوى در بعد استاندارد زندكى محروميت بيشترى داشتهاند.

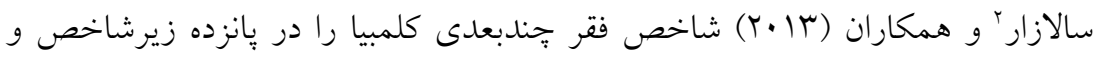
در قالب ينج بعد با سيستم وزندهى برابر و با آستانه فقر سه درصد محاسبه كردند. ابعاد و زيرشاخصها عبارتاند از: () شرايط آموزش خانوار r) شرايط آموزش نوجوانان و كودكان خانوار س) كار دربر گيرنده دو زيرشاخص نداشتن بيكارى بلندمدت و نيز داشتن شغل رسمى؛ ع) سلامت، داراى دو زيرشاخص داشتن بيمه سلامت و دسترسى به خدمات سلامت و بعد 
آخر، 0) دسترسى به امكانات رفاهى عمومى و شرايط مسكن. نتايج نشان داد فقر جندبعدى

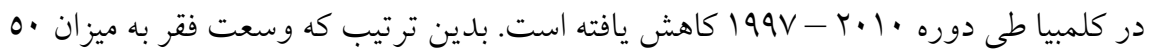
درصد و مقدار شاخص فقر جندبعدى معادل 00 درصد كاهش يافته|ند. بيشترين محروميت در تمامى سالها در زيرشاخصهاى اشتغال رسمى، ميانخين سطوح، بيمه درمانى و شكاف تحصيلى است.

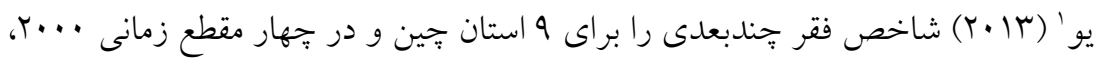

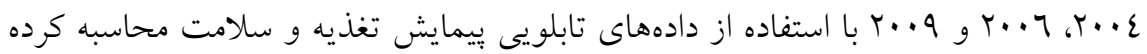
است. بدين منظور هشت زيرشاخص در قالب ينج بعد در نظر گرفته شده است كه عبارتاند از: درآمد، دسترسى به آب، دسترسى به امكانات بهداشتى، برق، سوخت بختويز، سلامت،

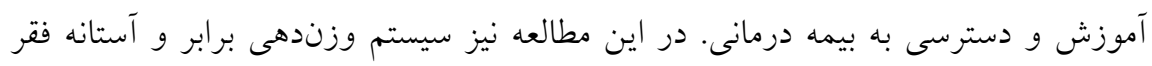
•0 درصد در نظر كرفته شده است. نتايج نشان داد وسعت فقر و همجنين ميزان شاخص فقر جندبعدى طى دوره در هر دو مناطق شهرى و روستايى كاهش يافته است. بررسيها نيز

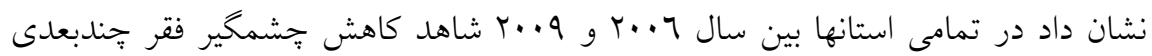
بوده است. علت اين امر تحت يوشش بيمه قرار گرفتن مناطق شهرى و روستايى استانها بوده است. علاوه بر اين ميزان محروميت در هر يك از زيرشاخصها طى دوره كاهش يافته است و بيشترين ميزان كاهش در زيرشاخص بيمه درمانى به ميزان كان درصد بوده است. بررسى سهم هر يك از زيرشاخصها در شاخص فقر جندبعدى نيز نشان داد بيشترين سهم را به ترتيب زيرشاخص بيمه و درآمد به خود اختصاص دادهاند. آلتاميرنو و داميانوץ (T (Y. Y) با استفاده از شاخص فقر جندبعدى آلكاير و فوستر به مقايسه وضعيت فقر خانوارهاى با سريرست زن و مرد در نيكاراكوئه يرداختهاند. بدين منظور با 


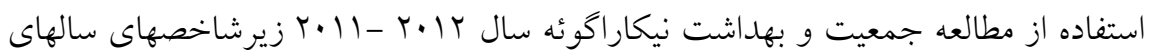
تحصيل، حضور فرزند در مدرسه، مرگومير كودكان، تغذيه و همجنين زيرشاخصهاى برق، دفع فاضلاب، دسترسى به آب آشاميدنى سالم، كف اتاق، سوخت يختويز، تملك دارايى، نحوه تصرف مسكن و تعداد اتاقهاى در اختيار را در قالب سه بعد آموزش، سلامت و استاندارد زندگى در نظر گرفتند. براى هر يك از ابعاد نيز وزن م/1 و براى زيرشاخصهاى دو بعد آموزش و سلامت وزن 1/7 و براى زيرشاخصهاى بعد استاندارد زندكى وزن ع/T/ در نظر كرفته شده است. نتايج نشان داد كه با آستانه فقر س/ بس درصد در خانوارهايى كه مرد سريرست است محروميت بيشترى را در اكثر زيرشاخصها تجربه كردند و سبس خانوارهايى كه در آنها مادر بهتنهايى سريرست است در رتبه دوم قرار دارد. خانوارهايى كه در آنها هردوى و الدين حضور دارند و زن سريرست خانوار است محروميت كمترى نسبت به دو گروه قبلى

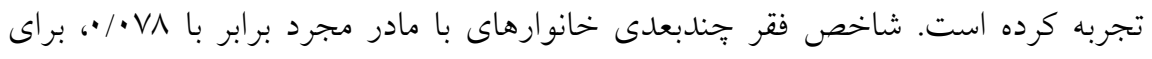
خانوارهاى با سريرست زن معادل ع7 • • و خانوارهايى با سربرست مرد برابر با ب ال / • است. وسعت فقر در خانوارهاى با مادر مجرد برابر IV/T درصد و در خانوارهاى با حضور هردوى والدين ولى زن سريرست برابر با س/عا درصد بوده است. در خانوارهاى با سريرست مرد اين نسبت معادل /ع/0 درصد است. با آستانه فقر •0 درصد نيز در خانوارهاى با سريرست مرد فقر شديد بيشتر است. بيشترين محروميت در زير شاخص سالهاى تحصيل، حضور در مدرسه، مرگومير كودك و سوخت براى بختوبيز و كمترين محروميت در دسترسى به آب آب آشاميدنى براى هر سه گروه است. مقايسه شاخص فقر جندبعدى مناطق شهرى و روستايى نيز نشان داد كه ميزان وسعت و شدت فقر و همجنين شاخص فقر جندبعدى در مناطق روستايى نسبت به مناطق شهرى براى هر سه گروه سريرست خانوار بيشتر است. آكبودجى' و همكاران (r|r.|r) براى محاسبه ميزان نابرابرى جنسيتى در بوركينافاسو 
و توگو (آفريقاى غربى) از رويكرد فقر جندبعدى آلكاير و فوستر استفاده كرده و ابعاد

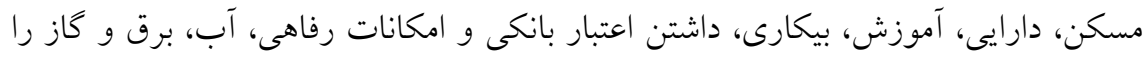

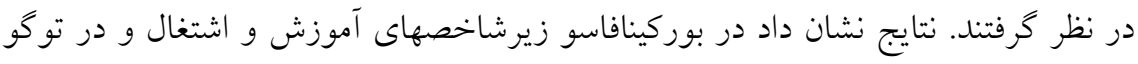

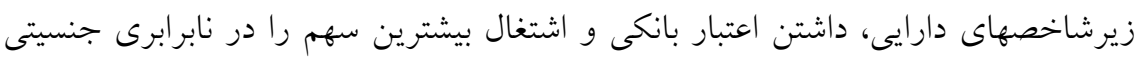

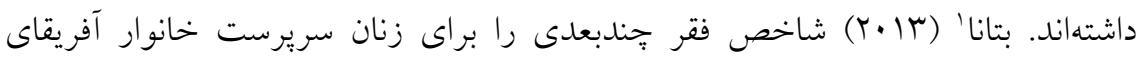

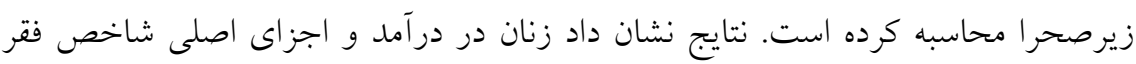
جندبعدى مانند آموزش و تملك دارايى از مردان محرومتر هستند.

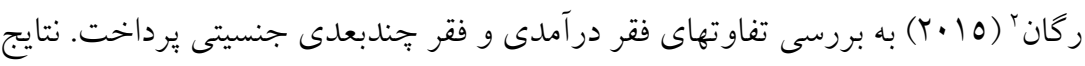

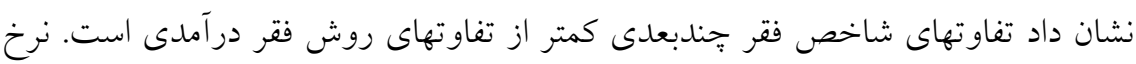

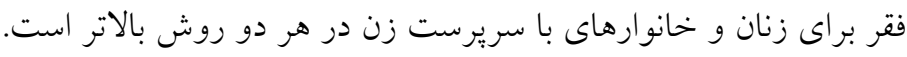

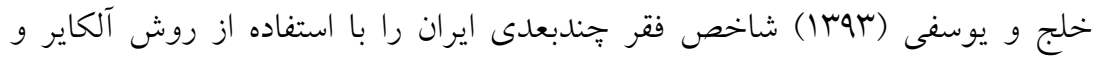

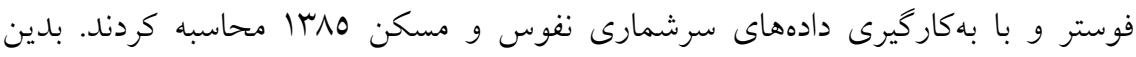

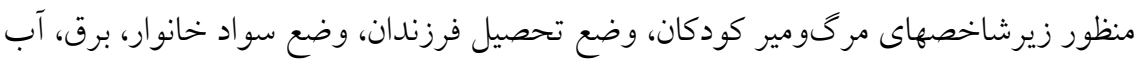

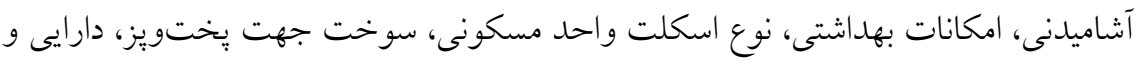

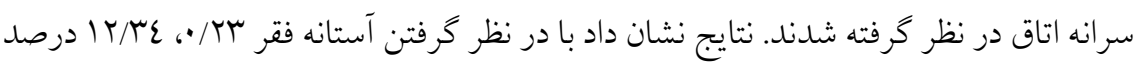

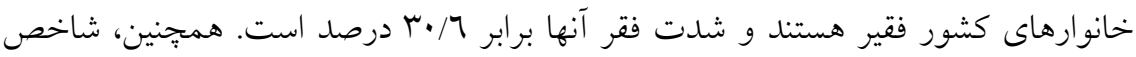

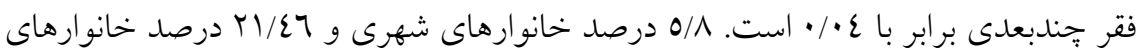
روستايى فقيرند. شدت فقر در خانوارهاى روستايى الr/07 درصد و در خانوارهاى شهرى لهرى 1N/1N درصد است. بيشترين محروميت خانوارهاى كشور در زيرشاخصهاى داريى، وضع سواد خانوار و نوع اسكلت واحد مسكونى است. در خانوارهاى شهرى، بيشترين محروميت در 
زيرشاخصهاى وضع سواد خانوار و دارايى است. درحالى كه بيشترين محروميت در خانوارهاى روستايى در زيرشاخصهاى دارايى، نوع اسكلت واحد مسكونى و وضع سواد خانوار است.

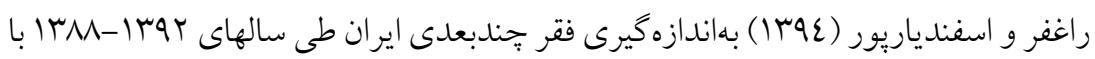
استفاده از روش آلكاير و فوستر براى كل كشور و برحسب مناطق شهرى و روستايى برداختند.

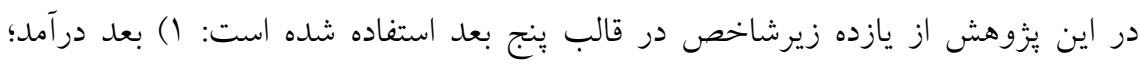

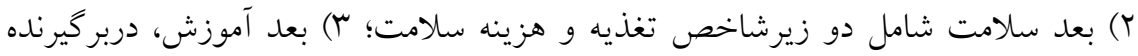

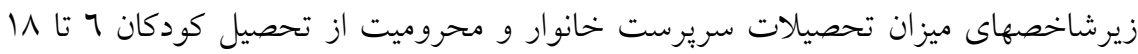

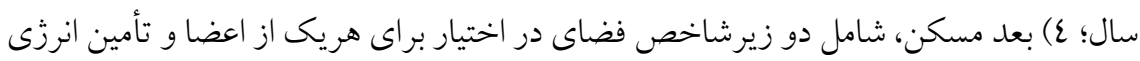

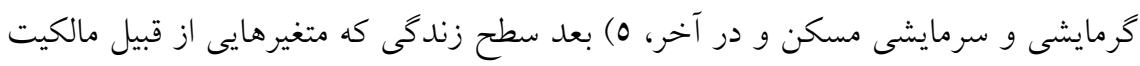

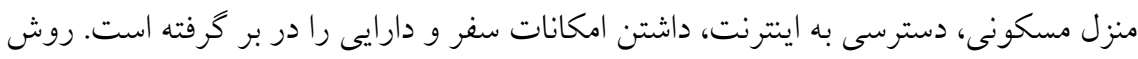

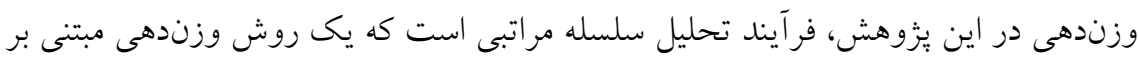

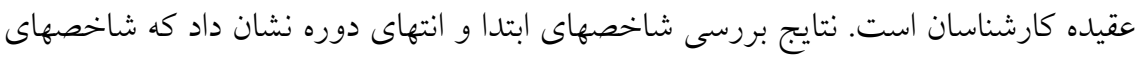
فقر جندبعدى در طول دوره تا سال الجه| داراى روندى كاهشى بودهاند و كمترين اندازه تمام

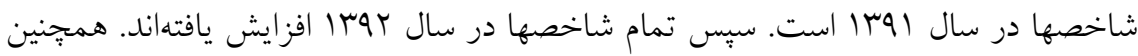

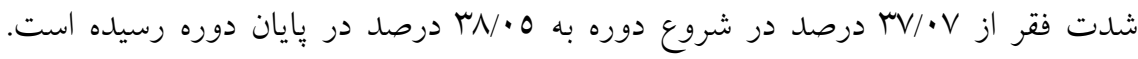
علاوه بر اين، نتايج نشان داد در تمامى سالها بيشترين نسبت سرشمار ينهانى به ترتيب در برد

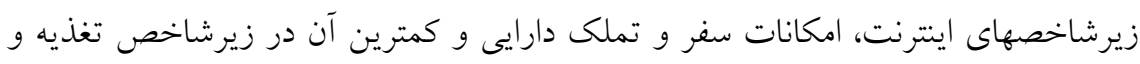
هزينه سلامت است.

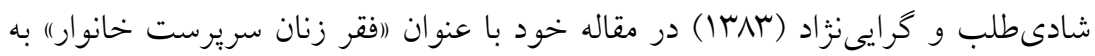
بررسى وضعيت فقر مطلق و نسبى زنان سريرست خانوار در سه مقطع از يك دوره لـ ل1 ساله

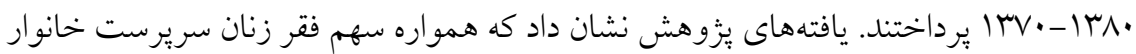


بيشتر از مردان سريرست خانوار بوده است و زن بودن احتمال قرار كرفتن در دايره فقر را

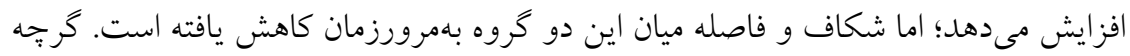

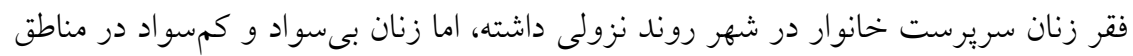

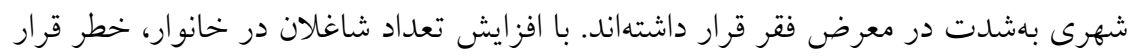

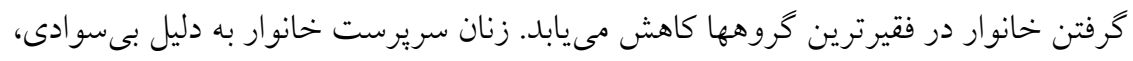

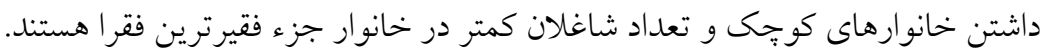

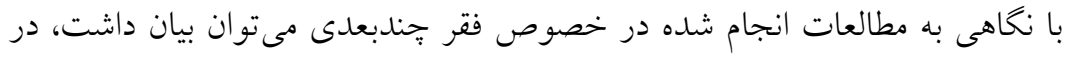

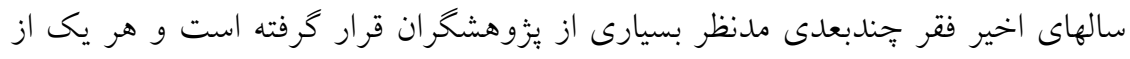

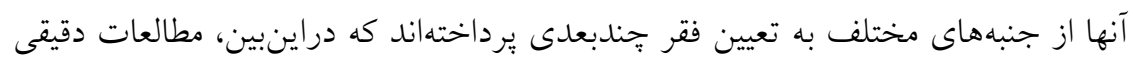

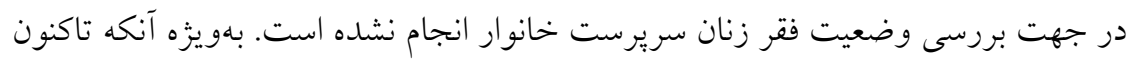

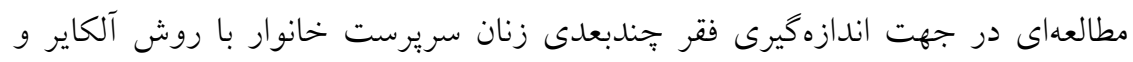

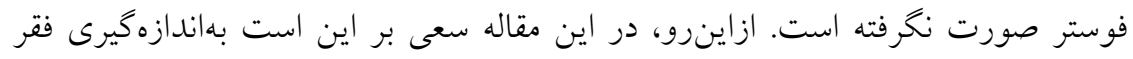

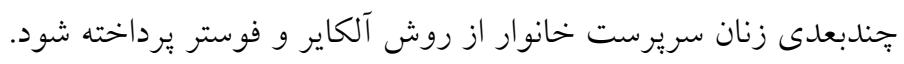

مر احل محاسبه شاخص فقر جندبعدى

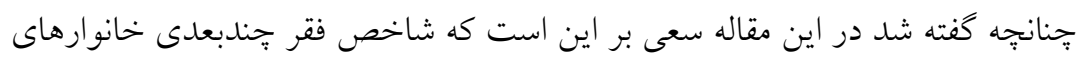
زن سريرست و مرد سريرست به روش آلكاير و فوستر و به تفكيك مناطق شهرى و و روستايى محاسبه شود. اين روش شامل دو مرحله است. در مرحله اول شناسايى افراد

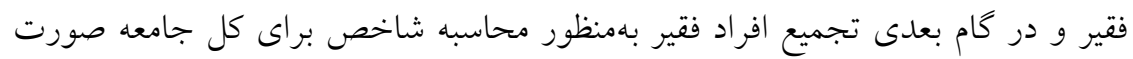

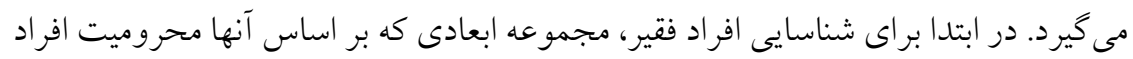

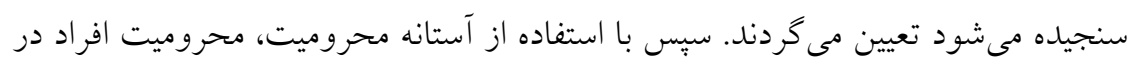


هر يك از ابعاد مشخص مىشود. منظور از آستانه محروميت سطح مشخصى از دسترسى فرد به زيرشاخص موردنظر است تا در صورت دسترسى به ميزانى كمتر از آن محروم در نظر كرفته شود. محروميتها در هر يك از ابعاد اهميت نسبى يكسانى ندارند و مىتوان از طريق وزن دادن به آنها ميزان اهميت آنها را تعيين كرد. يس از تعيين محروميت افراد در هر يكى از ابعاد مىتوان نمره محروميت هر فرد را از طريق جمع وزنى محروميتهاى وى به دست آورد. درواقع اين نمره يا ميزان محروميت، عمق محروميت هر فرد را در همه ابعاد نشان مىدهد. سبِ شناسايى افراد فقير با استفاده از آستانه فقر صورت مى گيرد. اخر ميزان محروميت فرد برابر با آستانه فقر يا بيشتر از آن باشد فرد فقير است و در غير اين صورت فقير نيست. بس بس از شناسايى افراد فقير فرآيند تجميع براى كل اقتصاد صورت مى گيرد.

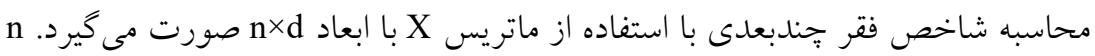
تعداد افراد و d ابعاد موردنظر هستند. در اين صورت، عنصر X مر ماتريس X ميزان دسترسى فرد i را در بعد j نشان مىدهد. براى هر يك از ابعاد يك آستانه محروميت بهصورت zj نظر گرفته مىشود؛ بنابر اين بردار آستانه محروميت (z, براى فرد در هر بعد را نشان مىدهد تا در صورت دسترسى به آن غير محروم در نظر گرفته شود. اخر ميزان دسترسى فرد در بعد j از آستانه محروميت مرتبط با آن (z) كمتر باشد فرد در آن بعد محروم است و اخر ميزان دسترسى فرد حداقل بهاندازه آستانه محروميت باشد فرد

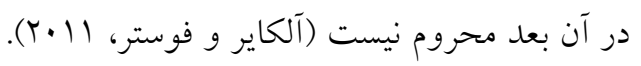
ماتريس محروميت $\left[g_{i j}\right]=g^{0}$ نشاندهنده افراد محروم در هر بعد است. به ازاى مقادير معين X) ماتريس محروميت g0 متشكل از اعداد صفر و يك است. هر عنصرى از ماتريس كه از آستانه محروميت مربوط به آن (z) كمتر باشد، فرد در آن بعد محروم است و در ماتريس محروميت با يك ( 1 مران 
محروميت مربوط به آن كمتر نباشد، فرد در آن بعد محروم نيست و در ماتريس محروميت با صفر ( محروميتهاى فرد i در همه ابعاد و بردار ستونى gيز كل افراد محروم در هر بعد را نشان مىدهد (آلكاير و روبلز، 10 • (Y). بردار وزن W=(w اهميت نسبى يكسانى داشته باشند وزن يكسانى به آنها تعلق مى گيرد و اخر بعدى اهميت بيشترى در تعيين افراد فقير داشته باشد وزن بيشترى را به خود اختصاص مىدهد. جمع وزنها نيز بايد برابر يك باشد. در روش آلكاير و فوستر از سيستم وزندهى برابر استفاده مىشود؛ بنابراين، هر يك از سه بعد سلامت، آموزش و استاندارد زندگى وزن زيرشاخصهاى هر بعد نيز وزن برابرى دارند؛ بنابراين، هريك از معيارهاى بعد سلامت و

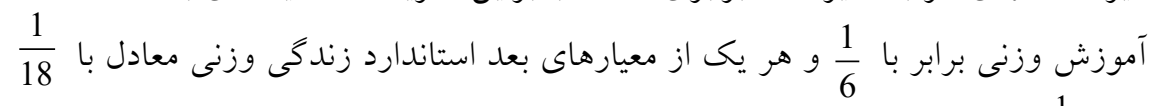

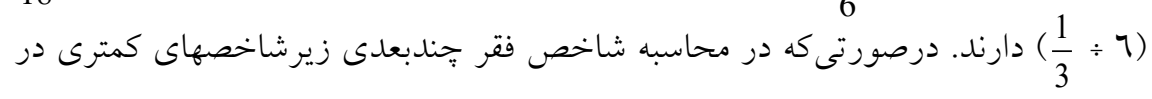
نظر گرفته شوند، وزنها متفاوت خواهند بود. بهعنوانمثال، اخر در كشورى به دليل محدوديت در جمعآورى دادهها اطلاعات مربوط به يكى از زيرشاخصهاى استاندارد زندگى در دسترس نباشد، در اين صورت هر يك از ع زيرشاخص بعدهاى سلامت و آموزش وزنى معادل با $\frac{1}{6}$ دارند و هر يكى از معيارهاى بعد استاندارد زندكى وزئ وزنى برابر

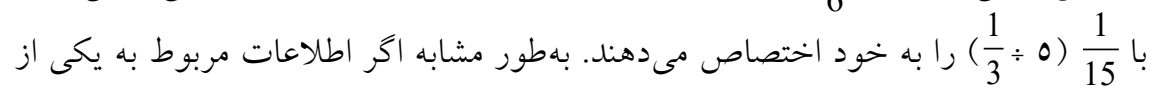
زيرشاخصهاى بعد آموزش موجود نباشد، در اين صورت هر يك از زيرشاخصهاى بعد سلامت وزنى معادل با $\frac{1}{6}$ دارند و هر يكى از معيارهاى بعد استاندارد زندگى وزنى برابر

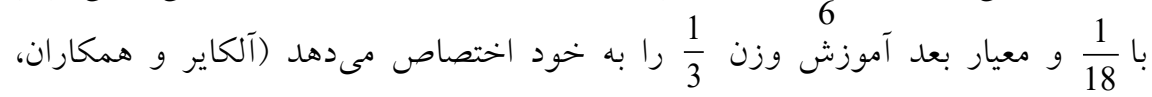


نمره محروميت هر فرد نيز از جمع وزنى محروميتهاى وى به دست مى آيد. نمره محروميت هر فرد با افزايش محروميت وى افزايش يافته و زمانى كه فرد در همه ابعاد محروم باشد به حداكثر مقدار خود مىرسد و اخر فردى در هيجيك از ابعاد محروم نباشد نمره

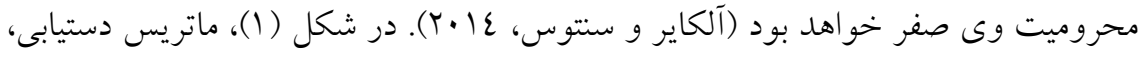
ماتريس محروميت، ماتريس نمره محروميت، بردار آستانهاى محروميت و همجنين بردار وزن آورده شده است.

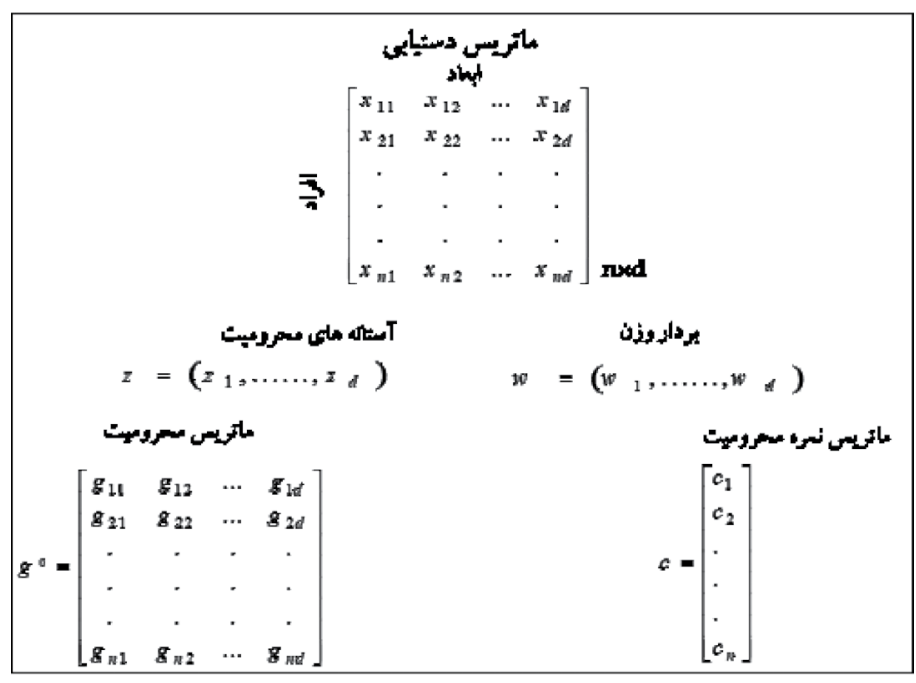

شكل (1) ماتريس دستيابى، ماتريس محروميت، ماتريس نمره محروميت، بردار آستانههاى محروميت و بردار وزن

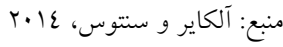

يس از تعيين ميزان محروميت افراد، شناسايى افراد فقير با استفاده از آستانه فقر صورت مى گيرد. آستانه فقر حداقل نمره محروميت لازم براى تعيين فرد فقير است. بِ از (k)g0 شناسايى افراد فقير براى محاسبه شاخص فقر از ماتريس محروميت حذفى (ينهانى) استفاده مىشود. ماتريس محروميت حذفى (k)g از ماتريس محروميت g0 به دست مى آيد. 
بدين ترتيب كه هر عنصر ماتريس محروميت حذفى حاصل ضرب عنصر متناظر در ماتريس محروميت در تابع شناسايى است؛ بنابراين اخر فردى فقير باشد وضعيت محروميت وى بدون تغيير باقى مانده و اطلاعات محروميت وى حفظ مىشود و درصورتى كه فردى فقير نباشد اطلاعات وى حذف خواهد شد (آلكاير و سانتوس، • (·+ץ)؛ بنابراين، شاخص فقر جندبعدى از اطلاعات افراد فقير استفاده مى كند و اطلاعات افراد محرومى را كه فقير نيستند در نظر نمى گيرد. بردار نمره محروميتهاى حذفى ccli نيز از ماتريس محروميت حذفى به دست

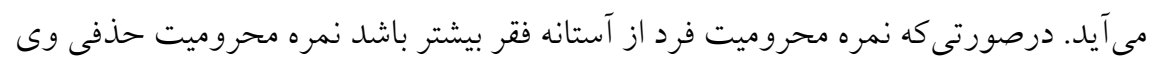
با نمره محروميت وى برابر خواهد بود و اكر نمره محروميت فرد از آستانه فقر كمتر باشد نمره محروميت حذفى وى برابر صفر است. در شكل (Y)، ماتريس نمره محروميت، ماتريس محروميت ينهانى و همجنين ماتريس نمره محروميت بنهانى آورده شده است.

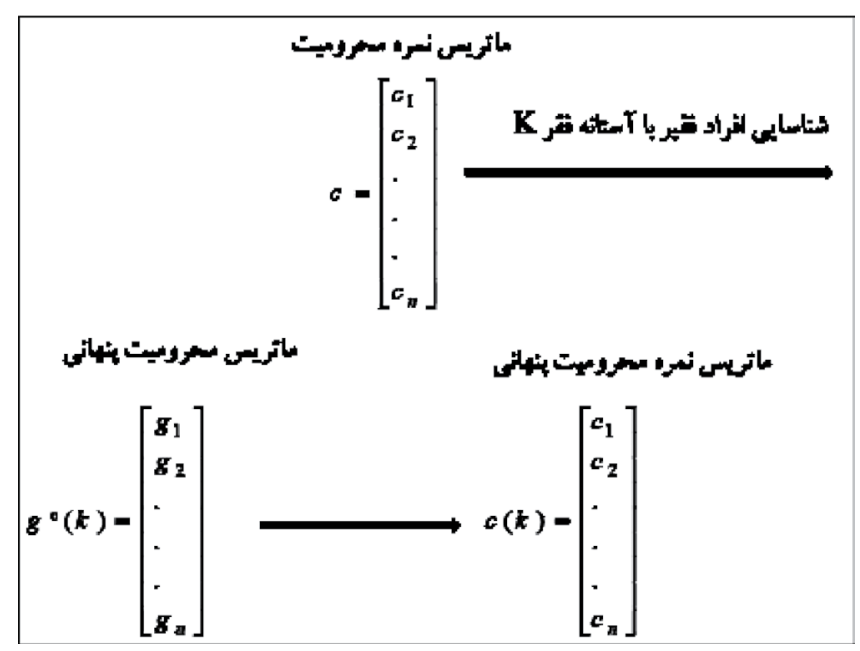

شكل (Y) ماتريس نمره محروميت، ماتريس محروميت پينهانى و ماتريس نمره محروميت ينهانى 
پِ از شناسايى افراد فقير، مىتوان شاخص فقر جندبعدى را از طريق ميانگين ماتريس

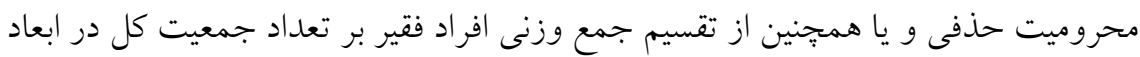

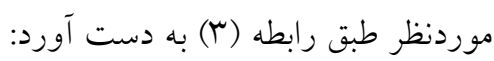

$M P I=\mu(c(k))=\frac{1}{n} \times \sum_{i=1}^{n} c_{i}(k)$

\section{وسعت و شدت فقر}

براى نشان دادن وسعت و شدت فقر زنان سريرست خانوار مىتوان شاخص فقر جندبعدى (MPI) را از تركيب دو مجموعه اطلاعات مهم به دست آورد (آلكاير و همكاران،

نسبت سرشمار קندبعدى 'H(y,z)=H كه نسبت افراد فقير به كل جمعيت است و

$$
\begin{aligned}
& \text { از رابطه (ع) به دست مى آيد (ارضرومجيلر، ع^با): } \\
& H=\frac{q}{n}
\end{aligned}
$$

در اين رابطه، q تعداد افراد فقير و جمعيت كل است. نسبت سرشمار H وسعت فقر را

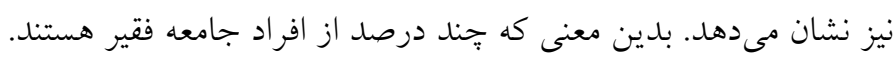
(Y) شدت فقر A، نسبت متوسط (وزنى) محروميتى است كه افراد فقير تجربه مى كنند.

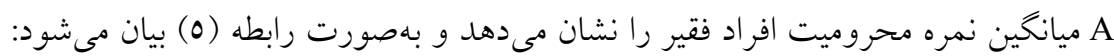

$$
A=\frac{\sum_{i=1}^{n} c_{i}(k)}{q}
$$

در اين رابطه ch ميزان محروميت ينهانى فرد i و تعداد افراد فقير است. در اين صورت

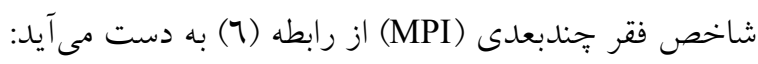
$M P I=H \times A=\frac{q}{n} \times \frac{1}{q} \sum_{i=1}^{q} c_{i}(k)=\frac{1}{n} \sum_{i=1}^{n} c_{i}(k)=\frac{1}{n} \sum_{i=1}^{n} \sum_{j=1}^{d} w_{j} g_{i j}^{0}$

1. multidimensional headcount ratio 
بر اساس رابطه (7)، شاخص فقر جندبعدى حاوى اطلاعاتى است كه وسعت و شدت فقر را نشان مىدهد. ازاينرو به آن نسبت سرشمار تعديلشده (

تفكيك شاخص فقر جندبعدى بر اساس زيرگروههاى جامعه اصلى

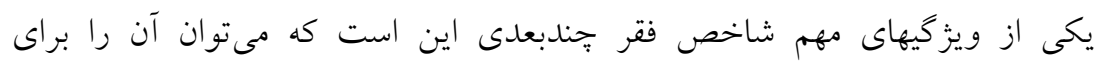

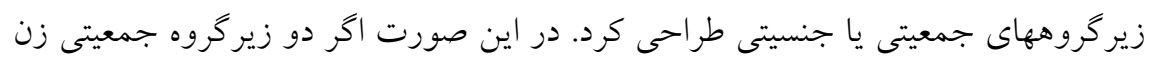

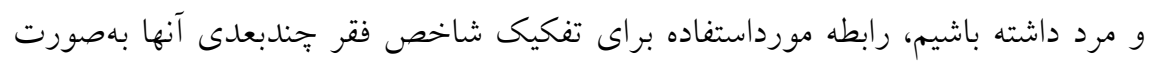
زير است:

$$
M P I=\frac{n_{F}}{n} M P I_{F}+\frac{n_{M}}{n} M P I_{M}
$$

كه در اين رابطه، $n_{F}$

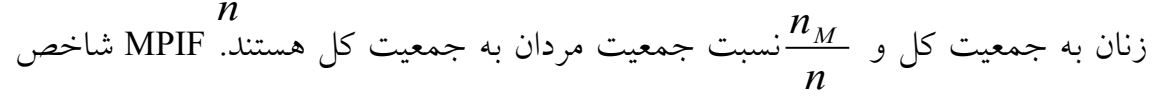

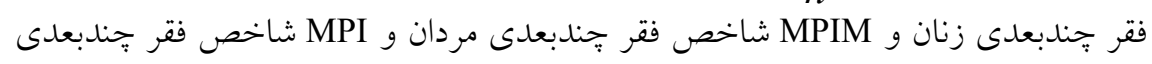

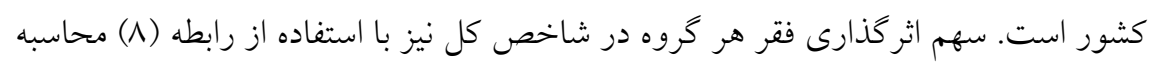

$$
\frac{\frac{n_{i}}{n} M P I_{i}}{M P I} \times 100
$$
مىشود:

اساس رابطه (N) اخر اثر گذارى گروه موردنظر در شاخص فقر كل از نسبت جمعيت

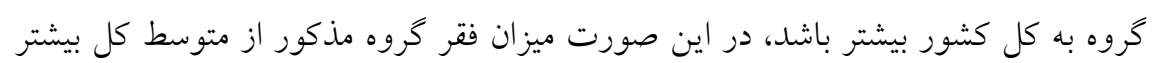
خواهد بود. 


\section{سهم هريك از ابعاد و زيرشاخصها در شاخص فقر حندبعدى}

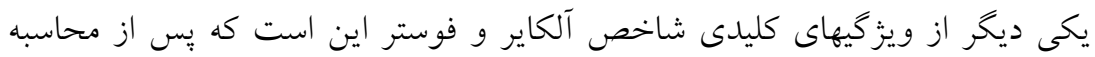

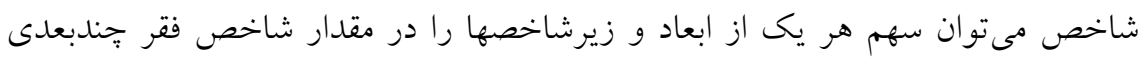

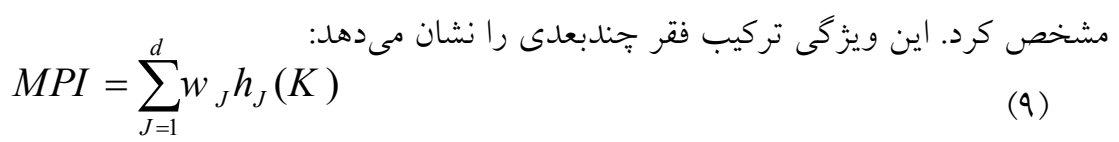

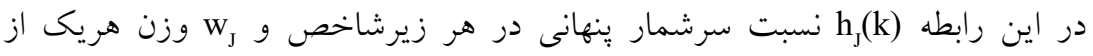

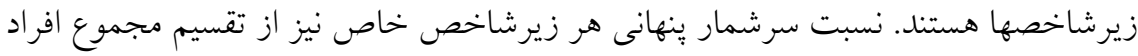

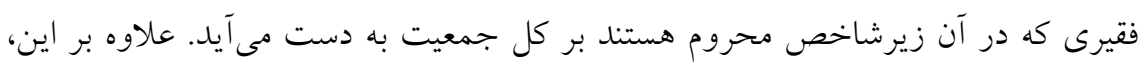

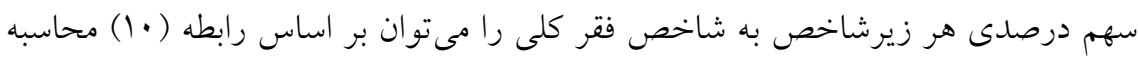

$$
\phi_{j}(k)=w_{j} \frac{h_{j}(k)}{M_{0}}
$$

درصورتى كه سهم افراد فقير از شاخص خاصى بهطور كستردهاى بيشتر از وزن آن باشد،

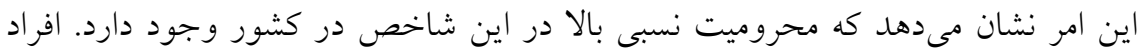

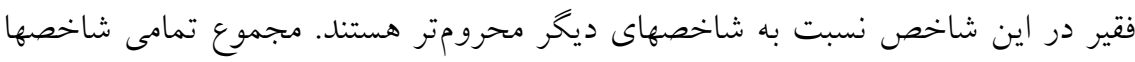
برابر ل.1 ادرصد است.

\section{شناسايى عوامل مؤثر بر فقر حندبعدى زنان سريرست خانوار}

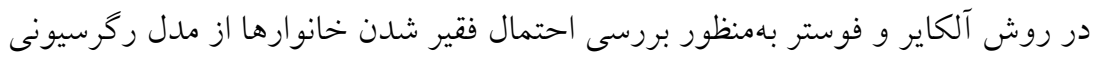

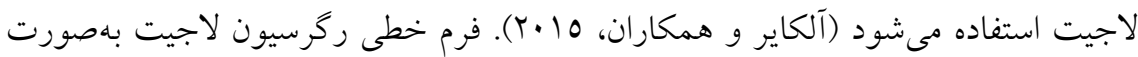

$$
\ln \frac{\pi_{i}}{1-\pi_{i}}=\beta_{0}+\beta_{1} x_{i 1}+\ldots+\beta_{k} x_{i k}
$$


در اين مدل

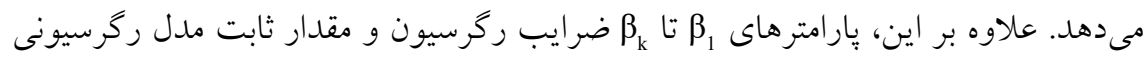

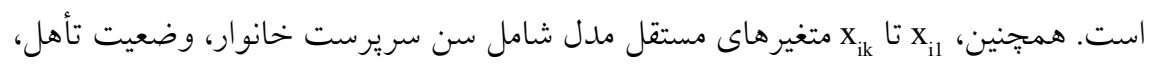

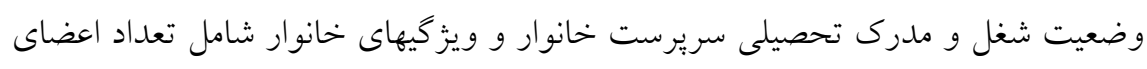
خانوار و روستايى بودن است.

\section{روش شناسى محاسبه شاخص فقر جندبعدى زنان و مردان سريرست خانوار در ايران}

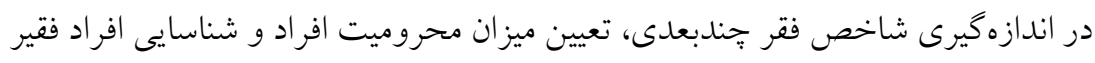

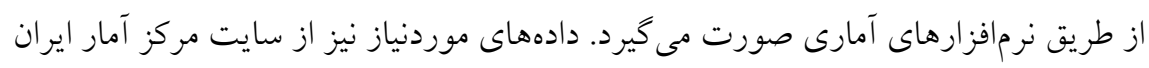

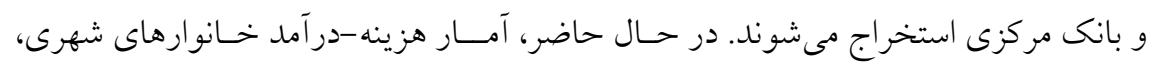

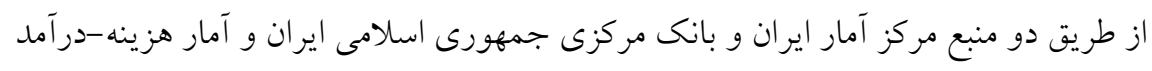

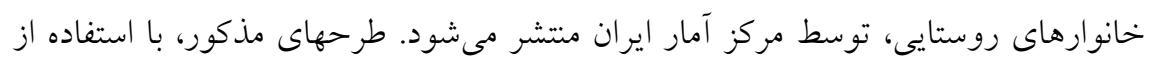

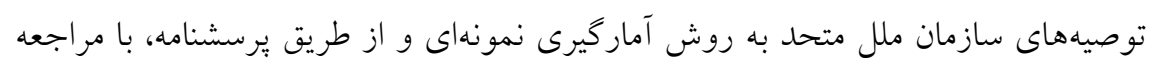

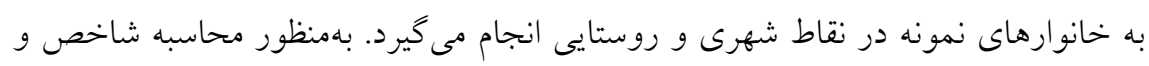

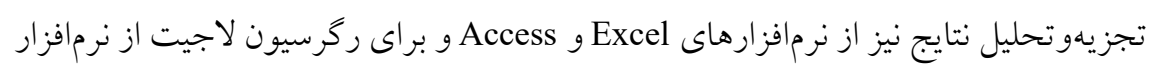
Stata بر اى محاسبه شاخص جندبعدى فقر زنان و مردان سريرست خانوار از دادههاى خام هزينه -

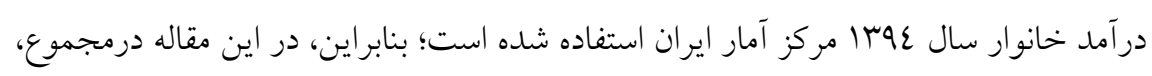

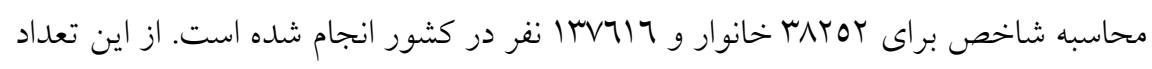
|MNV|

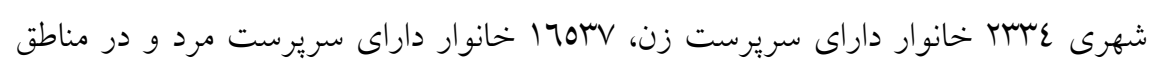

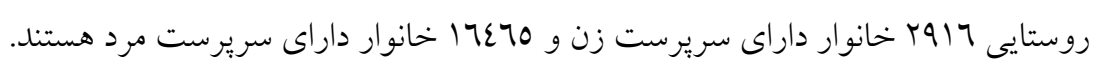


در اين مجموعه دادهاى خام، اطلاعات مربوط به دو بعد آموزش و استاندارهاى زندگى موجود است. هشت زيرشاخص موجود اين دو بعد عبارتاند از: سالهاى تحصيل، حضور

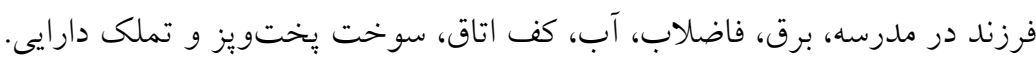

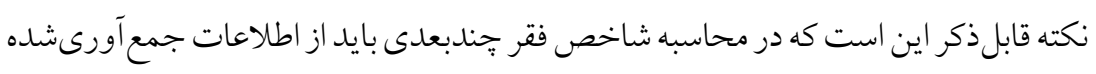

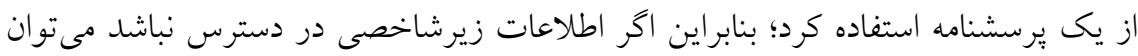

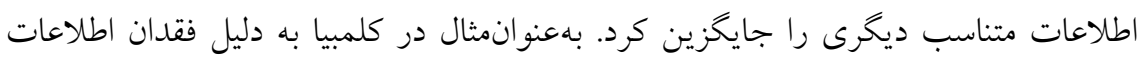

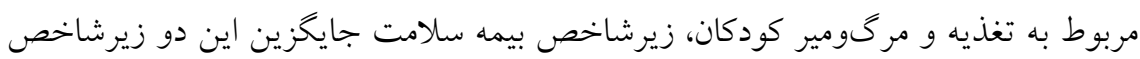

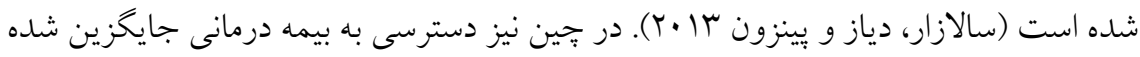

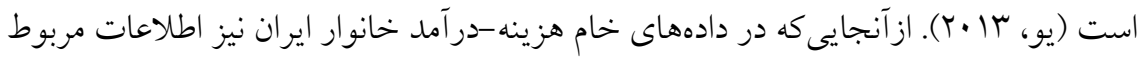
به بعد سلامت و دو زيرشاخص مرگُومير كودكان و تغذيه موجود نيست، ازاينروى، براى هرئه

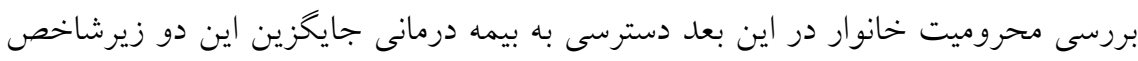

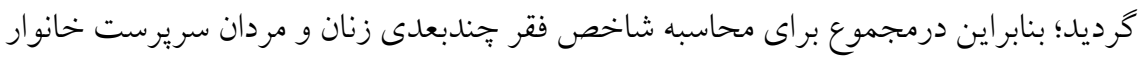

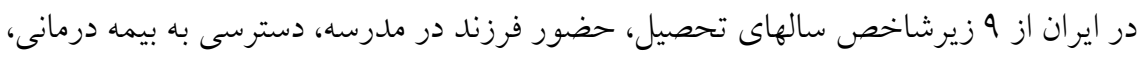

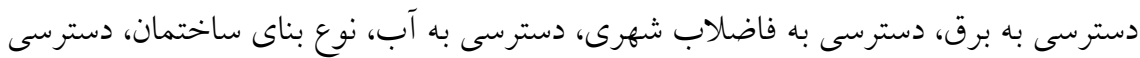

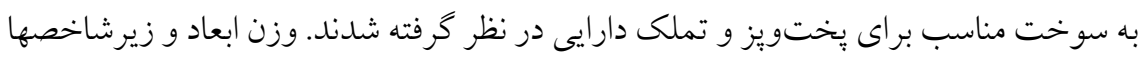
نيز بر اساس روش شاخص فقر جندبعدى جهانى و بر اساس سيستم وزندهى برابر انتخاب

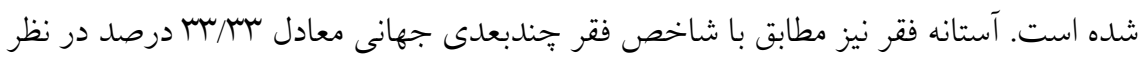

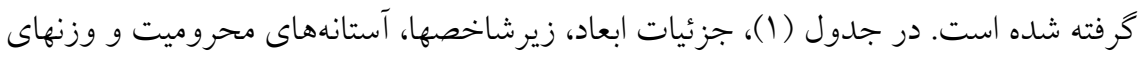

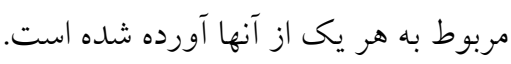


جدول ( (1) ابعاد، زيرشاخصها و وزنها براى محاسبه شاخص فقر جندبعدى

\begin{tabular}{|c|c|c|c|}
\hline 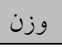 & محروم است اگر... & زيرشاخصها & 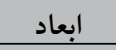 \\
\hline $1 / 7$ & 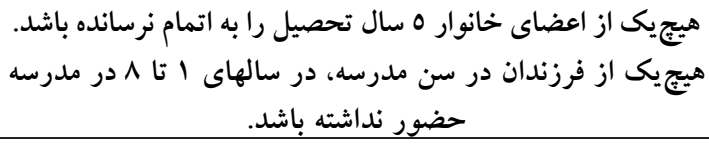 & سالهاى تحصيل & 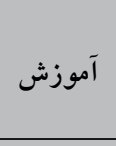 \\
\hline $1 / r$ & اعضاى خانوار بيمه درمانى نداشته باشند. & بيمه درمانى & سلامت \\
\hline $\begin{array}{l}1 / 1 \wedge \\
1 / 1 \wedge \\
1 / 1 \wedge \\
1 / 1 \wedge \\
1 / 1 \wedge\end{array}$ & 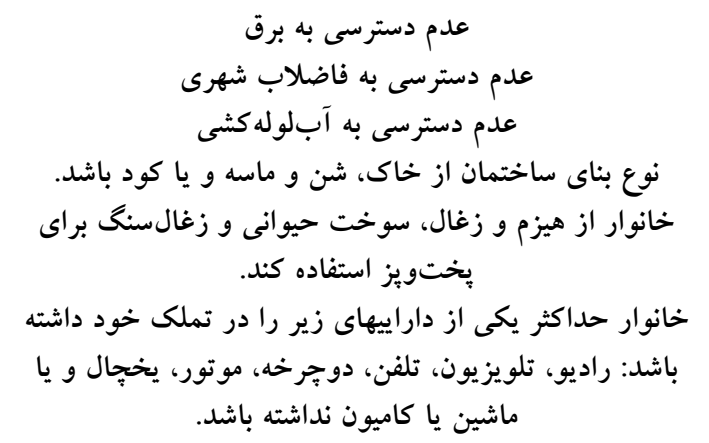 & 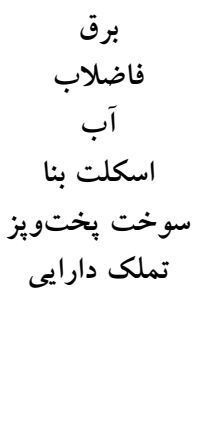 & زنداندارد \\
\hline
\end{tabular}

يافتهها

سنجش فقر جندبعدى زنان و مردان سربرست خانوار در مناطق شهرى و روستايى شاخص فقر جندبعدى زنان و مردان سريرست خانوار در مناطق شهرى و روستايى ايران به سال عqها در سه بعد آموزش، سلامت و استاندارد زندگى و براى 9 زيرشاخص سالهاى تحصيل، حضور فرزند در مدرسه، دسترسى به بيمه درمانى، دسترسى به برق، دسترسى به فاضلاب شهرى، دسترسى به آب، نوع بناى ساختمان، دسترسى به سوخت مناسب براى بختويز و تملك دارايى محاسبه شده است. نتايج حاصل از محاسبه شاخص فقر جندبعدى زنان و مردان سريرست خانوار در مناطق شهرى و روستايى ايران، نسبت سرشمار (وسعت فقر)، شدت فقر و همجنين سهم دو گروه زنان و مردان سريرست خانوار در شاخص فقر جندبعدى مناطق شهرى و روستايى سال عوسا در جداول (Y) و (r) آورده شده است. 
جدول (Y) شاخص فقر جِندبعدى زنان و مردان سربرست خانوار در مناطق شهرى ايران در سال عهبا

\begin{tabular}{|c|c|c|c|c|c|}
\hline 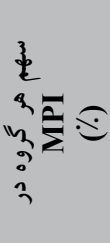 & 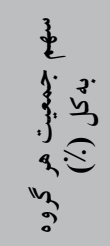 & 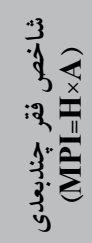 & $\begin{array}{l}3 . \\
3.3 \\
3.5 \\
3 \\
3 \\
3 \\
3 \\
3 \\
3\end{array}$ & $\begin{array}{c}3 \\
3 \\
3 \\
3\end{array}$ & \\
\hline$r \cdot / \Sigma V$ & $I T / T V$ &.$/ .9 \varepsilon r$ & $\varepsilon \Lambda / 1$. & 19/01 & زنان سريرست خانوار \\
\hline va/or & NV/ATr & .1 .017 & $\varepsilon r / 19$ & $\mid r / T \varepsilon$ & مردان سريرست خانوار \\
\hline $1 \ldots$ & $1 \ldots$ &.$/ .079$ & $\sum Y / 9 T$ & $15 / 10$ & كل مناطق شهرى \\
\hline
\end{tabular}

جنانجه در جدول (Y) آورده شده است، نسبت سرشمار جندبعلى زنان و مردان سريرست خانوار در مناطق شهرى به ترتيب معادل 19/01 و ع/T/ ا درصد است. بدين معنى است كه وسعت فقر در ميان زنان سريرست خانوار در مقايسه با مردان بيشتر است. ميانخين محروميت نيز نشان مىدهد كه شدت فقر در ميان زنان سريرست خانوار با رقم ^ع درصد از شدت فقر مردان سريرست خانوار با رقم بع درصد بيشتر است. بدين معنى است كه زنان سريرست خانوار در مقايسه با مردان در ابعاد بيشترى محروم هستند. درنهايت تفاوت

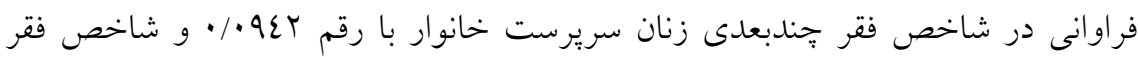
جندبعدى مردان سريرست خانوار با رقم 017 • • وجود دارد. باوجوداينكه زنان سريرست

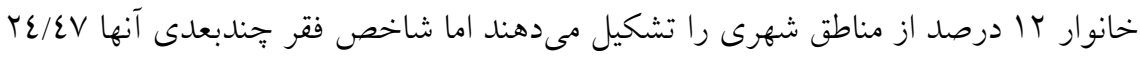
درصد از شاخص فقر جندبعدى مناطق شهرى را به خود اختصاص داده است. بر اساس رابطه (^) ازآنجايى كه اثر گذارى گروه زنان سريرست خانوار در شاخص فقر كل از نسبت جمعيت اين گروه به كل كشور بيشتر است، در اين صورت ميزان فقر زنان سربرست خانوار از متوسط كل بيشتر است. 
جدول (r) شاخص فقر جندبعدى زنان و مردان سريرست خانوار در مناطق روستايى ايران در سال ع عَ|

\begin{tabular}{|c|c|c|c|c|c|}
\hline 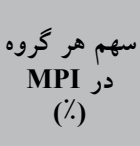 & هر كرمَروه بهيت & $\begin{array}{c}\text { شاخص } \\
\text { فقر } \\
\text { فندبعدى } \\
(\mathbf{M P I}=\mathbf{H} \times \mathbf{A})\end{array}$ & $\begin{array}{l}\text { محروميت } \\
\text { محين } \\
\text { (A) } \\
\text { (\%) }\end{array}$ & $\begin{array}{c}\text { سرشمار } \\
\text { (H) } \\
\text { (\%) }\end{array}$ & \\
\hline$T \varepsilon / W$ & $10 / .0$ &.$/ \cdot$ TVA & $01 / 29$ & $1 \pi / 1$ & زنان سريرست خانوار \\
\hline VO/rr & $\Lambda \varepsilon / 90$ & ع & $\varepsilon \varepsilon / 70$ & N/IV & مردان سريرست خانوار \\
\hline $1 \ldots$ & $1 \ldots$ & $\cdot / \cdot \varepsilon \mid r$ & ¿O/VY & $1 / 19$ & كل مناطق روستايى \\
\hline
\end{tabular}

جنانجه در جدول (r) آورده شده است، نسبت سرشمار جِندبعدى زنان و مردان سريرست خانوار در مناطق روستايى به ترتيب معادل • • N/IV درصد است. بدين معنى است كه وسعت فقر در ميان زنان سريرست خانوار در مقايسه با مردان بيشتر است. ميانگين محروميت نيز نشان مىدهد كه شدت فقر در ميان زنان سريرست خانوار با رقم 1/V9 درصد از شدت فقر مردان سريرست خانوار با رقم 70/20ع درصد بيشتر است. بدين معنى است كه زنان سريرست خانوار در مقايسه با مردان در ابعاد بيشترى محروم هستند. همجنين، نتايج نشان مىدهد تفاوت فراوانى در شاخص فقر جندبعدى زنان سريرست خانوار روستايى با رقم TV • • • و شاخص فقر جندبعدى مردان سريرست خانوار با رقم ع بr•• را تشكيل مى دهند اما شاخص فقر جندبعدى آنها r L/VV درصد از شاخص فقر جندبعدى مناطق روستايى را به خود اختصاص داده است. مقايسه فقر جندبعدى زنان سريرست خانوار مناطق شهرى و روستايى نشان مىدهد وسعت فقر زنان سريرست خانوار در مناطق شهرى بيشتر است؛ اما شدت فقر در مناطق روستايى بيشتر است، بدين معنى كه در مناطق روستايى زنان سريرست خانوار در ابعاد بيشترى محروم هستند. در جدول (ع) نسبت سرشمار و سهم هر يك از زيرشاخصها در شاخص فقر جندبعدى 
زنان و مردان سريرست خانوار در هر يك از ابعاد و زيرشاخصها در مناطق شهرى آورده

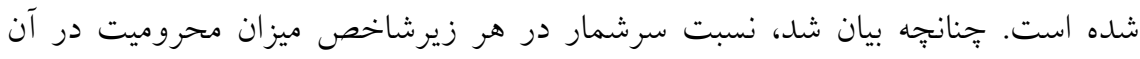

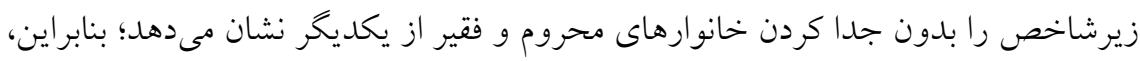

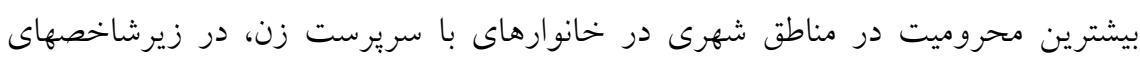
دسترسى به فاضلاب، تعداد سالهاى تحصيل و دسترسى به بيمه درمانى و بيشترين محروميت

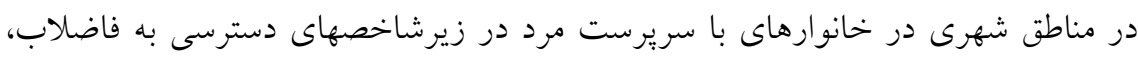

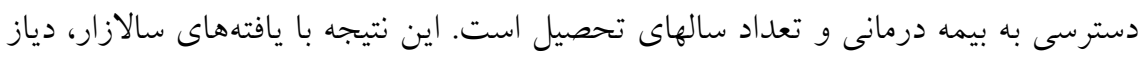

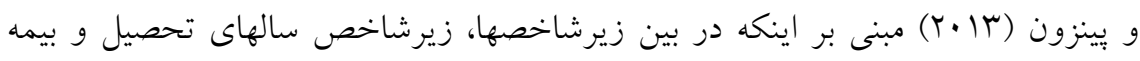

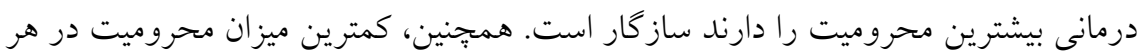

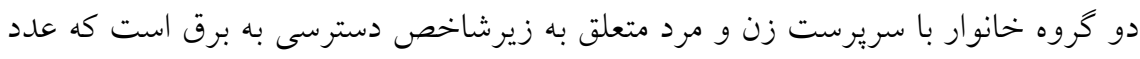

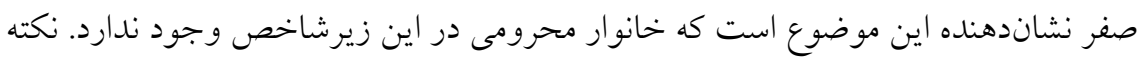

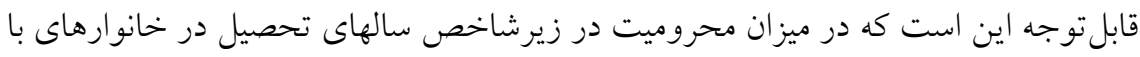

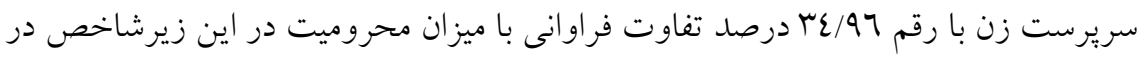

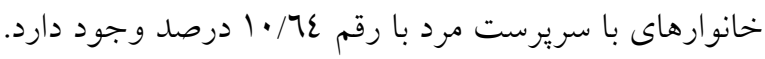


جدول (ع) نسبت سرشمار و سهم هر يك از زيرشاخصها در شاخص فقر جندبعدى زنان و مردان سريرست خانوار در مناطق شهرى

\begin{tabular}{|c|c|c|c|c|}
\hline \multicolumn{2}{|c|}{ مردان سريرست خانوار } & \multicolumn{2}{|c|}{ زنان سريرست خانوار } & \\
\hline $\begin{array}{c}\text { سهم هر زيرشاخص در } \\
\text { MPI } \\
(\%)\end{array}$ & نسبت سرشمار & $\begin{array}{c}\text { زيرشاخص در } \text { هر } \\
\text { MPI } \\
\text { (\%) }\end{array}$ & نسبت سرشمار & \\
\hline $7 / V_{1}$ & $1 \cdot / 7 \varepsilon$ & $1 / 190$ & $r \varepsilon / 97$ & سالهاى تحصيل \\
\hline $1 /$ ro $_{0}$ & $1 / \cdot r$ & $\cdot / \mathrm{u}$ & $\cdot / \mathrm{NV}$ & حضور در مدرسه \\
\hline VN/AT & $10 / \mathrm{V}$ & $T / \wedge \varepsilon$ & rr/Or & 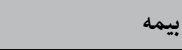 \\
\hline . & . & - & . & برق \\
\hline $\mid r / \varepsilon r$ & $V \cdot / \mu \Lambda$ & $9 / 94$ & $79 / 11$ & فاضلاب \\
\hline.$/ \cdot 1$ & $\cdot / \cdot \varepsilon$ & $\cdot / \cdot 1$ & $\cdot / \pi$ & آب \\
\hline$\cdot / 0 \varepsilon$ & $r / 9$ & $1 / 17$ & $V / \wedge \varepsilon$ & اسكلت بنا \\
\hline . & · & $\cdot / \cdot r$ &.$/ \cdot \varepsilon$ & سوخت يختويز \\
\hline$\cdot / 17$ & $\cdot / \mu \wedge$ & 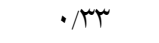 & $T / \Lambda \varepsilon$ & دارايى \\
\hline
\end{tabular}


جدول (0) نسبت سرشمار و سهم هر يك از زيرشاخصها در شاخص فقر جندبعدى زنان و مردان سريرست خانوار در مناطق روستايى

\begin{tabular}{|c|c|c|c|c|}
\hline \multicolumn{2}{|c|}{ مردان سريرست خانوار } & \multicolumn{2}{|c|}{ زنان سريرست خانوار } & \\
\hline $\begin{array}{c}\text { سهم هر زيرشاخص در } \\
\text { MPI } \\
(\%)\end{array}$ & نسبت سرشمار & سهم هر زيرشاخص در & نسبت سرشمار & \\
\hline $11 / \varepsilon r$ & $r Y / \cdot \varepsilon$ & $r Y / 1 T$ & $O r / \varepsilon$. & سالهاى تحصيل \\
\hline$r / 19$ & $\Gamma / \wedge \varepsilon$ & $\cdot / V 7$ & 1/No & حضور در مدرسه \\
\hline$V \cdot / v \wedge$ & $V / \Lambda$. & $7 T / 01$ & $1 T / V q$ & بيمه \\
\hline$\cdot / \cdot \varepsilon$ &.$/ .7$ & $\cdot / \cdot r$ & $\cdot / \cdot v$ & 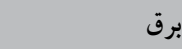 \\
\hline $\mid r / \varepsilon r$ & $99 / 70$ & $1 . / 7 \mathrm{~V}$ & $99 / 20$ & فاضلاب \\
\hline$\cdot / \varepsilon$. & r/vı & $\cdot / 70$ & $\varepsilon / 7$. & آب \\
\hline $1 / \varepsilon r$ & $1 Y / 9 V$ & $r / \tau \varepsilon$ & TY/TY & اسكلت بنا \\
\hline .1 .0 &.$/ 1 \wedge$ & $\cdot / \cdot r$ & $\cdot / \tau \varepsilon$ & سوخت پختويز \\
\hline$\cdot / T \wedge$ & $1 / 1 \wedge$ & .107 & $\mathrm{~V} / \mathrm{l}$. & 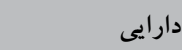 \\
\hline
\end{tabular}

در جدول (0) نسبت سرشمار و سهم هر يك از زيرشاخصها در شاخص فقر جندبعدى زنان و مردان سريرست خانوار در هر يك از ابعادو زيرشاخصها در مناطق روستايى آورده شده است. نتايج نشان داد بيشترين محروميت در مناطق روستايى در خانوارهاى با سريرست زن در زيرشاخصهاى دسترسى به فاضلاب، تعداد سالهاى تحصيل و اسكلت بنا است. محروميت خانو ارهاى با سريرست زن در زيرشاخص تعداد سالهاى تحصيل با رقم •ع/ع درصد در مقايسه با محروميت خانوارهاى با سريرست مرد با رقم ال درصد تفاوت فراوانى را نشان مىدهد. جّنانجه بيان شد، نسبت سرشمار ينهانى ميزان محروميت خانوارهاى محروم و درعين حال فقير را در زيرشاخصهاى مختلف نشان مى دهد. در نمودارهاى (r) و (ع) نسبت سرشمار ينهانى در هر يكى از زيرشاخصها در خانوارهاى با 
سريرست زن و مرد در مناطق شهرى و روستايى نشان داده شده است. بر اساس آنجه در شكلهاى (T)

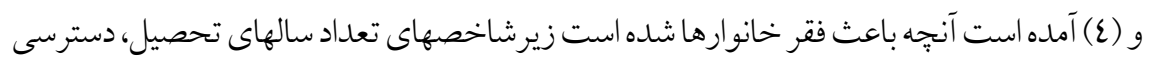
به بيمه درمانى و دسترسى به شبكه فاضلاب هستند. در هر سه اين زيرشاخصها ميزان محروميت خانوارهاى فقير زن سريرست از ميزان محروميت خانو ارهاى فقير مرد سريرست بيشتر است. بهويزه تفاوت بسيارى در زيرشاخص تعداد سالهاى تحصيل وجود دارد. محروميت در زيرشاخص تعداد

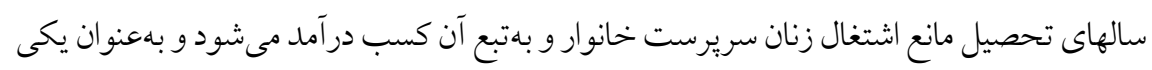
از عوامل فقر اين خانوارها در مقايسه با خانوارهاى با سريرست مرد به شمار مىرود. اين نتيجه مبنى

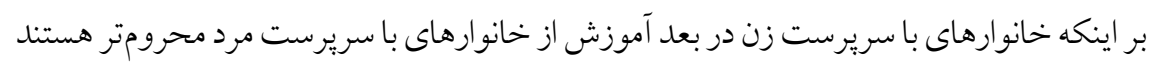

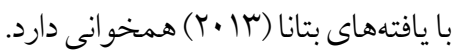

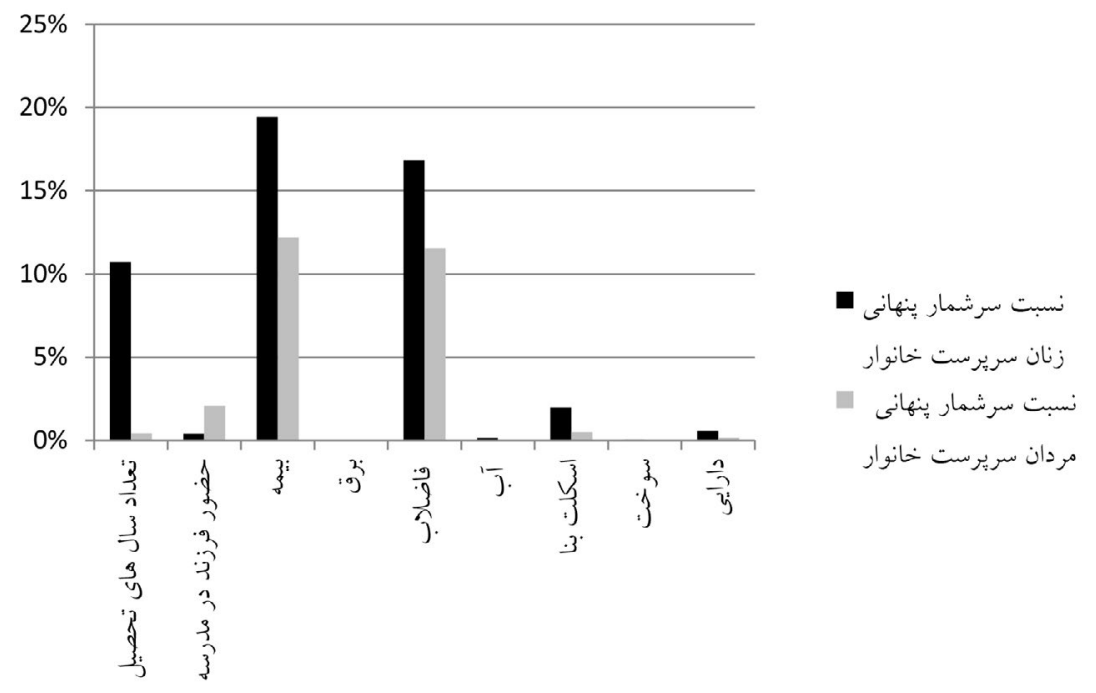

شكل (r) نسبت سرشمار بنهانى در هر يك از زيرشاخصها در خانوارهاى با سريرست زن و مرد در مناطق شهرى 


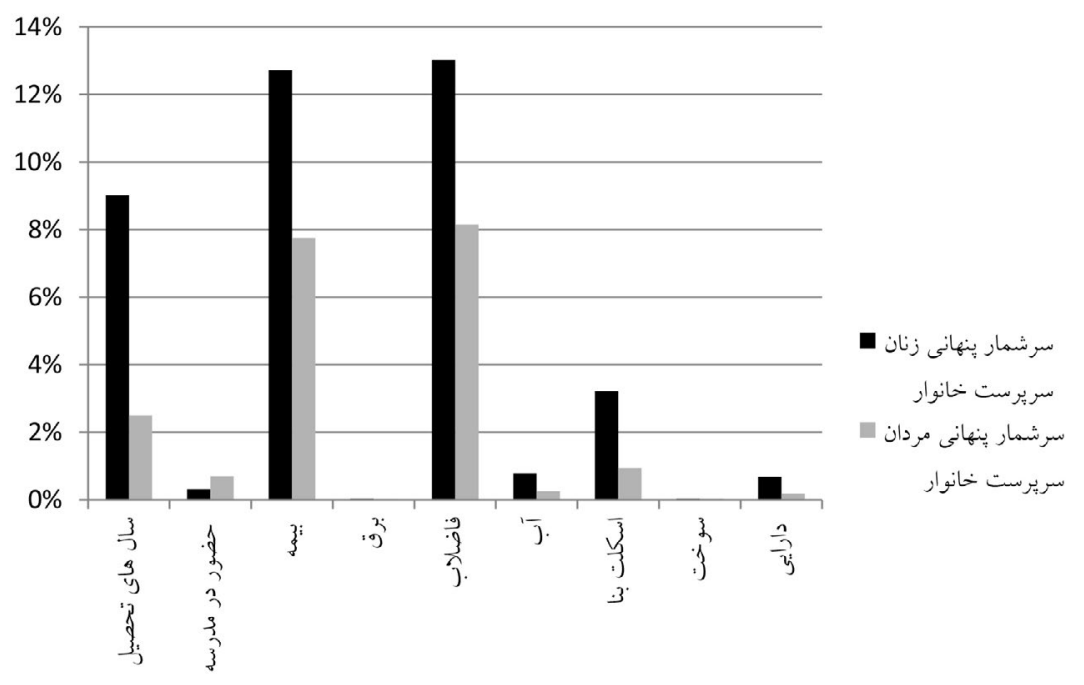

شكل (ع) نسبت سرشمار بنهانى در هر يك از زيرشاخصها

در خانوارهاى با سريرست زن و مرد در مناطق روستايى

بهمنظور مقايسه و بررسى وضعيت فقر خانوارهاى زن سريرست در مناطق شهرى و

روستايى، نسبت سرشمار در هر يك از زيرشاخصها در مناطق شهرى و روستايى در شكل

(0) (0) (1) آورده شده است. 


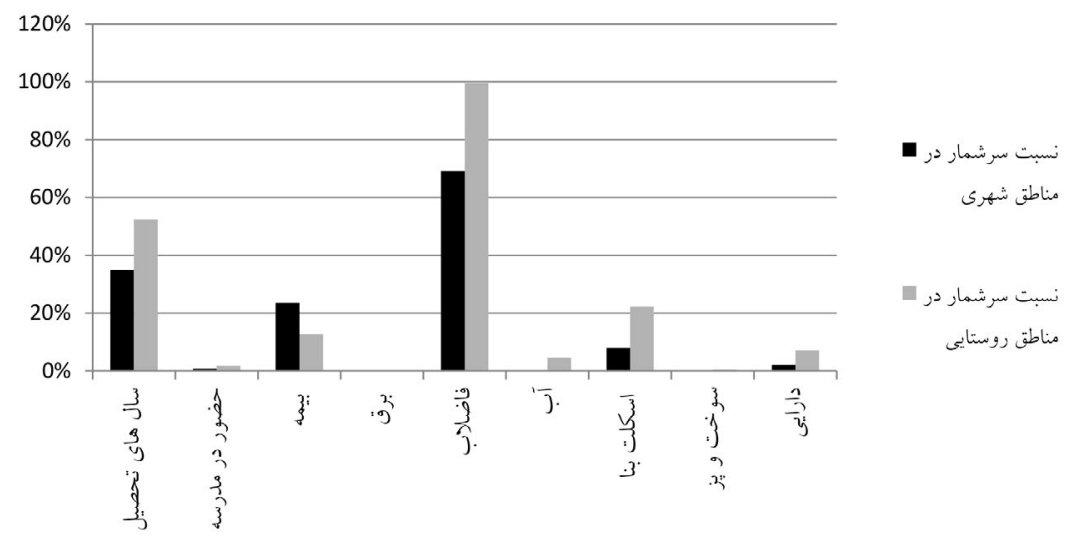

شكل (0) مقايسه نسبت سرشمار در هر يك از زيرشاخصها

در خانوارهاى زن سريرست در مناطق شهرى و روستايى

شكل (0) نشان مىدهد ميزان محروميت در خانوارهاى فقير زن سريرست در تمامى زيرشاخصها بهجز در زيرشاخص بيمه در مناطق روستايى از مناطق شهرى بيشتر است. بهطوركلى برنامه دولت در جهت توسعه روستايى از طريق تعميم و كسترش بيمه روستايى و

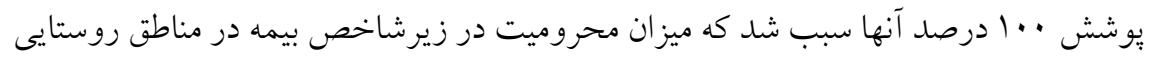

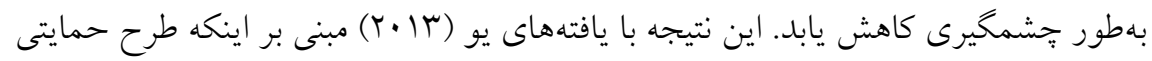
دولت در زيرشاخص بيمه سبب كاهش محروميت افراد در آن زيرشاخص شده است سازگار است. ميزان محروميت در زيرشاخصهاى تعداد سالهاى تحصيل، فاضلاب و نوع اسكلت بنا در مناطق روستايى در مقايسه يا مناطق شهرى تفاوت فراوانى را نشان مىدهد. 


\section{0. شناسايى عوامل مؤثر بر فقر جندبعدى زنان سريرست خانوار}

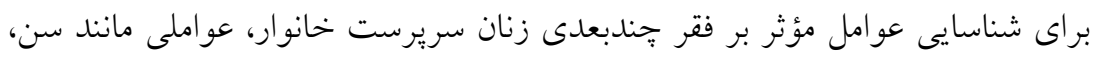

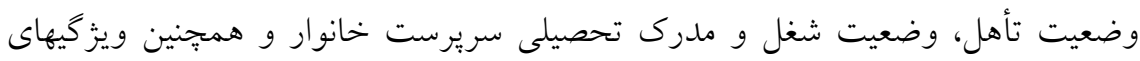

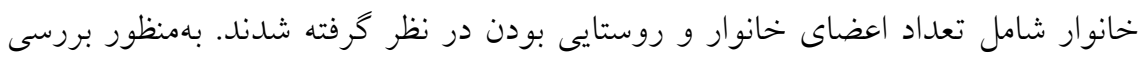

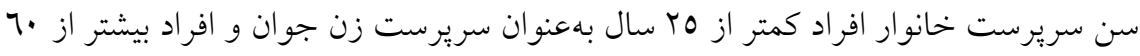
سال بهعنوان سريرست زن مسن در نظر گرفته شدهاند. علاوه بر اين، ازنظر وضعيت تأهل

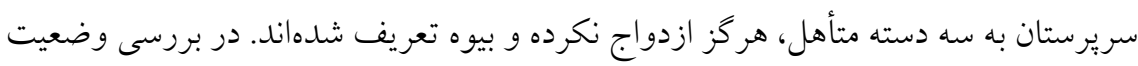

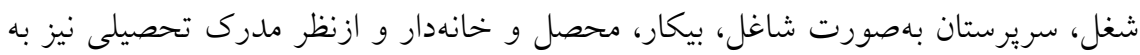

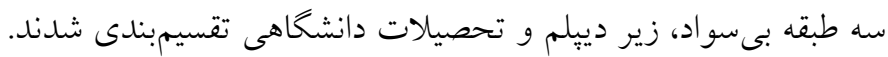

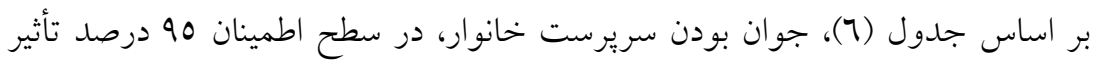

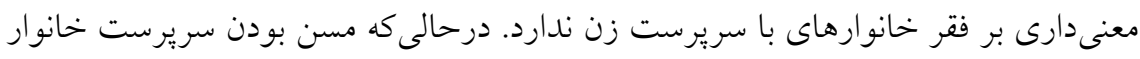

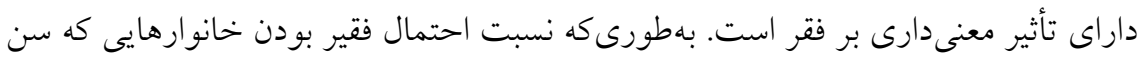

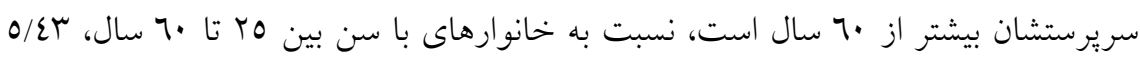
درصد بيشتر است كه مىتواند به دليل كاهش توانايى سريرست زن مسن در كار كردن و

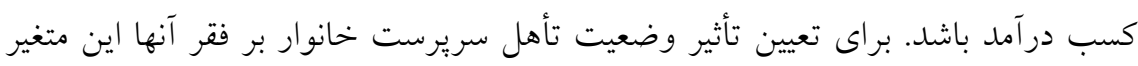

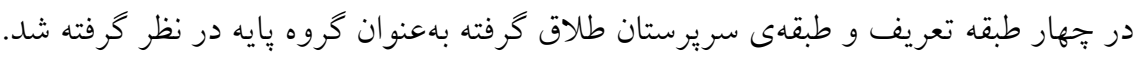

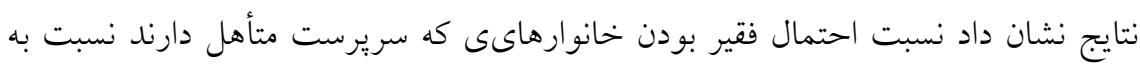

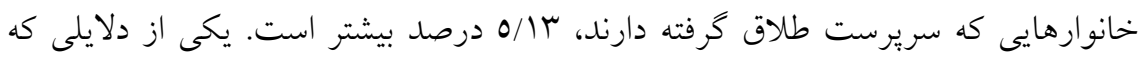
براى اين موضوع قابل بحث است اين است كه در مواردى كه سريرست زن خانوار متأهل

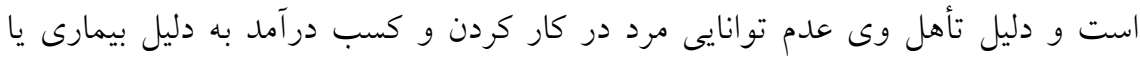
ازكارافتادكى باشد سبب مىشود بار هزينهاى بيشترى به خانوار تحميل شود. علاوه بر اين

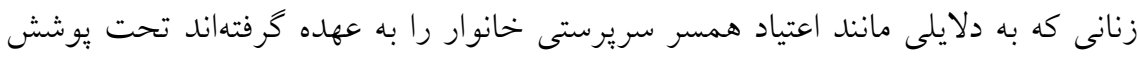


سازمانهاى حمايتى مانند كميته امداد قرار نمى گيرند و اين سبب مىشود كه احتمال فقير

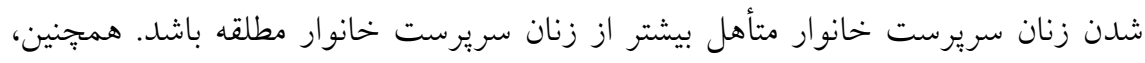

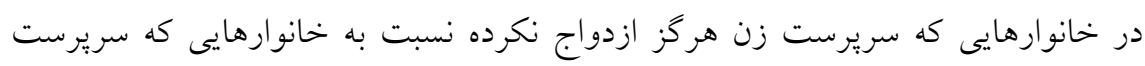

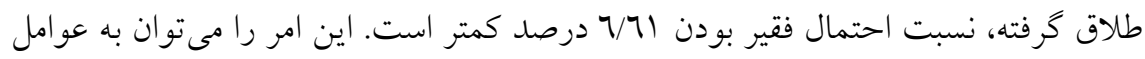
فرهنكى نيز نسبت داد، يافتن شغل براى زنان مطلقه سخت نتر از زنان هركز ازدواج نكرده

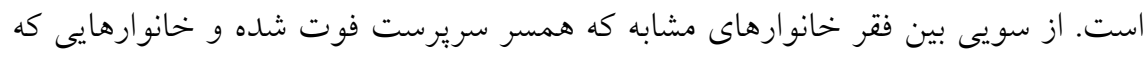
سريرستشان طلاق گرفته، نسبت احتمال فقير بودن V حرصد كمتر است. اين امر مى متواند

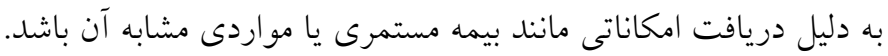

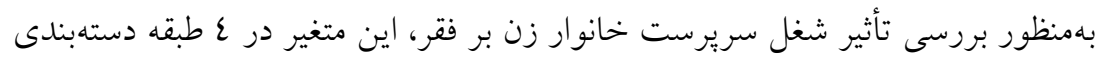

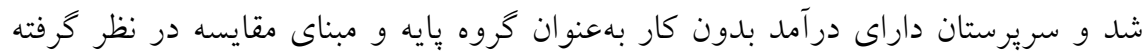

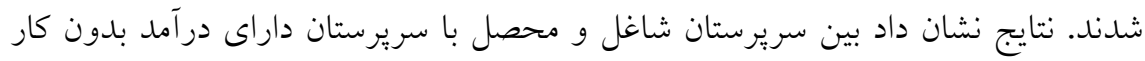
اختلاف معنى دارى وجود ندارد؛ اما بيكار بودن سريرست زن احتمال فقير بودن خانوار را بسار 19 درصد و خانهدار بودن سريرست خانوار احتمال فقير بودن خانوار را N/N درصد افزايش

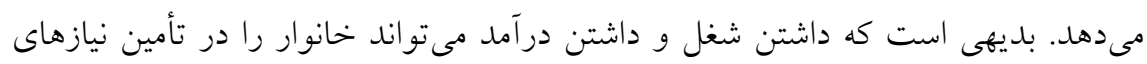

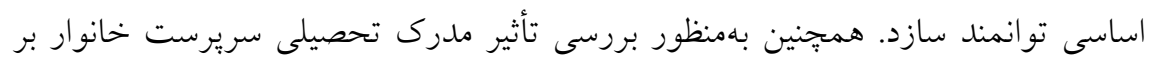

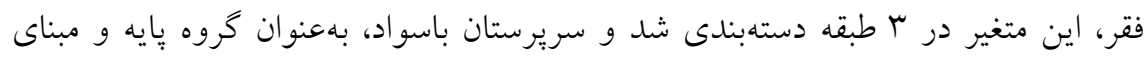

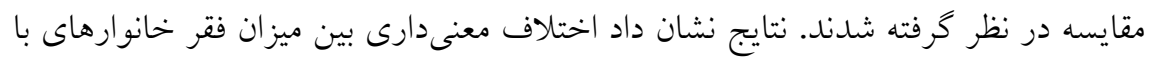

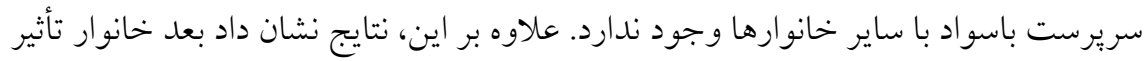

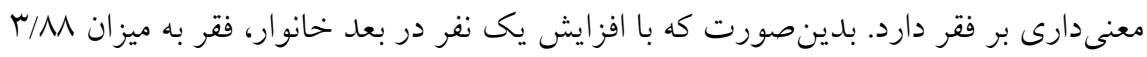

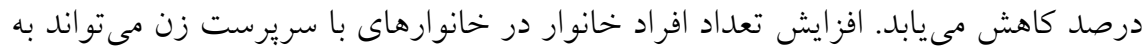

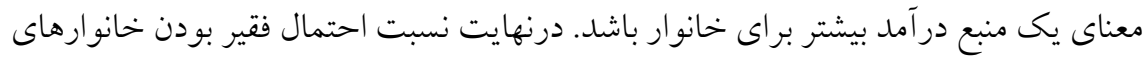
روستايى در مقايسه با خانوارهاى شهرى V/N درصد كمتر است. در مناطق روستايى زنان 
سريرست خانوار با اشتغال در بخش كشاورزى، داميرورى، صنايعدستى و يا مشاغل خانكى در مقايسه با زنان سريرست خانوار در مناطق شهرى ازنظر يافتن شغل داراى مزيت هستند كه سبب مىشود احتمال فقير بودن در مناطق روستايى كمتر از مناطق شهرى باشد. درنهايت، مىتوان كفت اين نتايج با يافتهاى شادىطلب و كرايىنزاد (rیr|) كه با افزايش تعداد شاغلان در خانوار، خطر قرار گرفتن خانوار در فقيرترين گروهها كاهش مى يابد و همجنين اينكه زنان سريرست خانوار به دليل داشتن خانوارهاى كوجى و تعداد شاغلان كمتر در خانوار جزء فقيرترين فقرا هستند ساز گار است. جدول (7) عوامل مؤثر بر فقر جندبعدى زنان سريرست خانوار

\begin{tabular}{|c|c|c|c|c|c|c|}
\hline اثرات نهايى & احتمال & آماره Z & انحراف استاندارد & ضريب & \multicolumn{2}{|c|}{ متغير } \\
\hline 0/11 & ( & $\cdot / 9$ & $\cdot / \varepsilon$. & & كمتر از Y سال & \multirow{2}{*}{ سن } \\
\hline $0 / \varepsilon r$ & $<\cdot / \cdots 1$ & $\varepsilon / \varepsilon$. &.$/ 1$ & $\cdot / \varepsilon \varepsilon$ & بيشتر از •7 سال & \\
\hline$-V / \cdot 7$ & $<\cdot 1 \cdots 1$ & $-r / 91$ & $\cdot / \mathrm{V}$ & $-\cdot 101$ & بى همسر براثر فوت & \multirow{3}{*}{ وضعيت تأهل } \\
\hline $0 / 1 \pi$ & .1 .0 & $1 / 97$ & .119 & $\cdot / \mu V$ & متأهل & \\
\hline$-7 / 71$ & $\cdot / \cdot r$ & $-Y / T V$ & $\cdot / 79$ & $-\cdot / 74$ & هر گز ازدواج نكرده & \\
\hline$-\cdot / \wedge$ & $\cdot / 7 r$ & $-\cdot / 2 q$ & - (1/ & $-\cdot / \cdot 7$ & 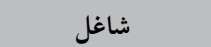 & \multirow{4}{*}{ 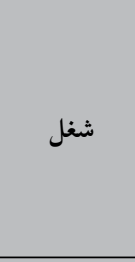 } \\
\hline $19 / \cdot r$ & $\cdot / \cdot r$ & $r / \mu \cdot$ & $\cdot / \varepsilon V$ & $1 / \cdot 9$ & بيكار & \\
\hline$r \pi / \varepsilon 7$ &.$/ 1 \wedge$ & $1 / \Gamma 1$ & $\cdot / 91$ & $1 / 79$ & محصل & \\
\hline$\Lambda / \wedge \cdot$ & 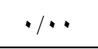 & $0 / 0 \varepsilon$ & .111 &.$/ 71$ & خ & \\
\hline $1 / 91$ & $\cdot / \varepsilon \varepsilon$ & $\cdot / V 7$ & $\cdot / r$. & .110 & بعسواد & \multirow{3}{*}{ تحصيلات } \\
\hline .1 .9 &.$/ 9 V$ & $\cdot / \cdot \varepsilon$ & $\cdot / \pi 1$ & $\cdot / \cdots V$ & زير دييلم & \\
\hline$r / 90$ & سח/. &.$/ 97$ & . & $\cdot / T Y$ & دانشگاهى & \\
\hline -r/AN & $<\cdot 1 \cdots 1$ & $-\Lambda / \varepsilon \mu$ & $\cdot / \cdot r$ & $-\cdot / \mu$ & \multicolumn{2}{|c|}{ بعد خانوار } \\
\hline$-\mathrm{V} / \mathrm{\mu} \Lambda$ & $\cdot / \cdots$ & $-V / Y T$ & $\cdot / \cdot 1$ &.$- \cdot 101$ & \multicolumn{2}{|c|}{ روستايى بودن } \\
\hline
\end{tabular}




\section{بحث}

نتايج تحقيق مبنى بر اندازهكيرى فقر جندبعدى خانوارهاى زن سريرست با استفاده از روش آلكاير و فوستر در سال عqها نشان داد كه شاخص فقر هُندبعدى خانوارهاى

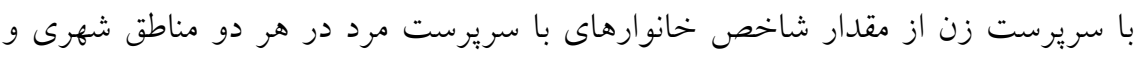
روستايى بيشتر است كه نشاندهنده لزوم توجه بيشتر به زنان سريرست خانوار در برنامهاى كاهش فقر است. بيشترين محروميت خانوارهاى با سريرست زن در مناطق شهرى در زير شاخصهاى دسترسى به شبكه فاضلاب، تعداد سالهاى تحصيل و دسترسى به بيمه درمانى و بيشترين محروميت در مناطق روستايى در زيرشاخصهاى دسترسى به شبكه فاضلاب، تعداد سالهاى تحصيل و نوع اسكلت بنا است. ازنظر برنامهريزى براى كاهش فقر، زيرشاخص تعداد سالهاى تحصيل اهميت بسيارى دارد؛ زيرا توانمند شدن زنان سريرست خانوار در لر بعد آموزش به معنى توانيى يافتن شغل و كسب درآمد است. كسب درآمد علاوه بر اينكه

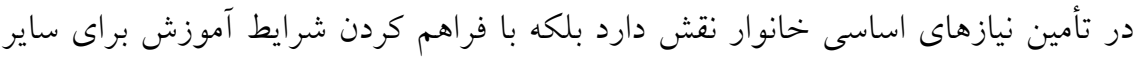
اعضاى خانوار ازجمله فرزندان به خروج خانوار از دام فقر در نسلهاى بعدى خانوار نيز كمك مى كند. همجنين نتايج نشان داد كه ميزان محروميت خانوارهاى با سريرست زن در تمامى زيرشاخصها بهجز در زيرشاخص دسترسى به بيمه در مناطق روستايى از مناطق شهرى بيشتر است. علاوه بر اين، ميزان محروميت در زيرشاخصهاى تعداد سالهاى تحصيل، دسترسى به شبكه فاضلاب و نوع اسكلت بنا در مناطق روستايى در مقايسه با مناطق شهرى

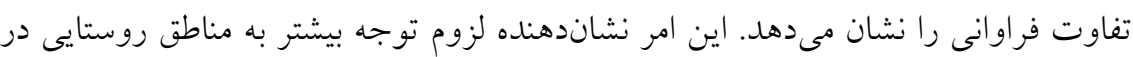
مقايسه با مناطق شهرى ازنظر اجر ایى طرحهاى حمايتى و تخصيص منابع است. نتايج حاصل از رگرسيون لاجستيك نيز نشان مىدهد كه زنان سريرست خانوار مسن، بيكار و خانهدار و همجينين زنان سريرست خانوار متأهل بيشتر نيازمند حمايت هستند و بايد در اولويت 
برنامهاى كاهش فقر قرار گيرند. همانگ كونه كه در فرآيند يُزوهش مشاهده شد، يكى از مزاياى روش آلكاير و فوستر قابليت تفكيكيذيرى به گروههاى جمعيتى يا جنسيتى و تعيين فردين

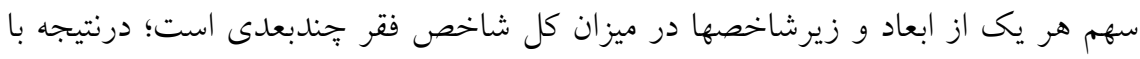
استفاده از اين روش مىتوان نشان داد كه افزايش و كاهش فقر در هر كروه ناشى از تغييرات

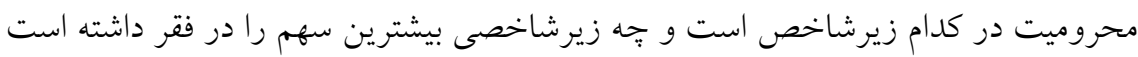

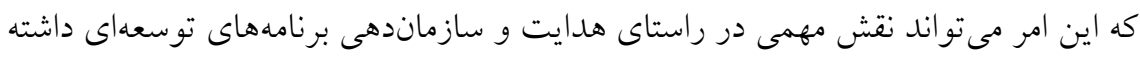
باشد. 


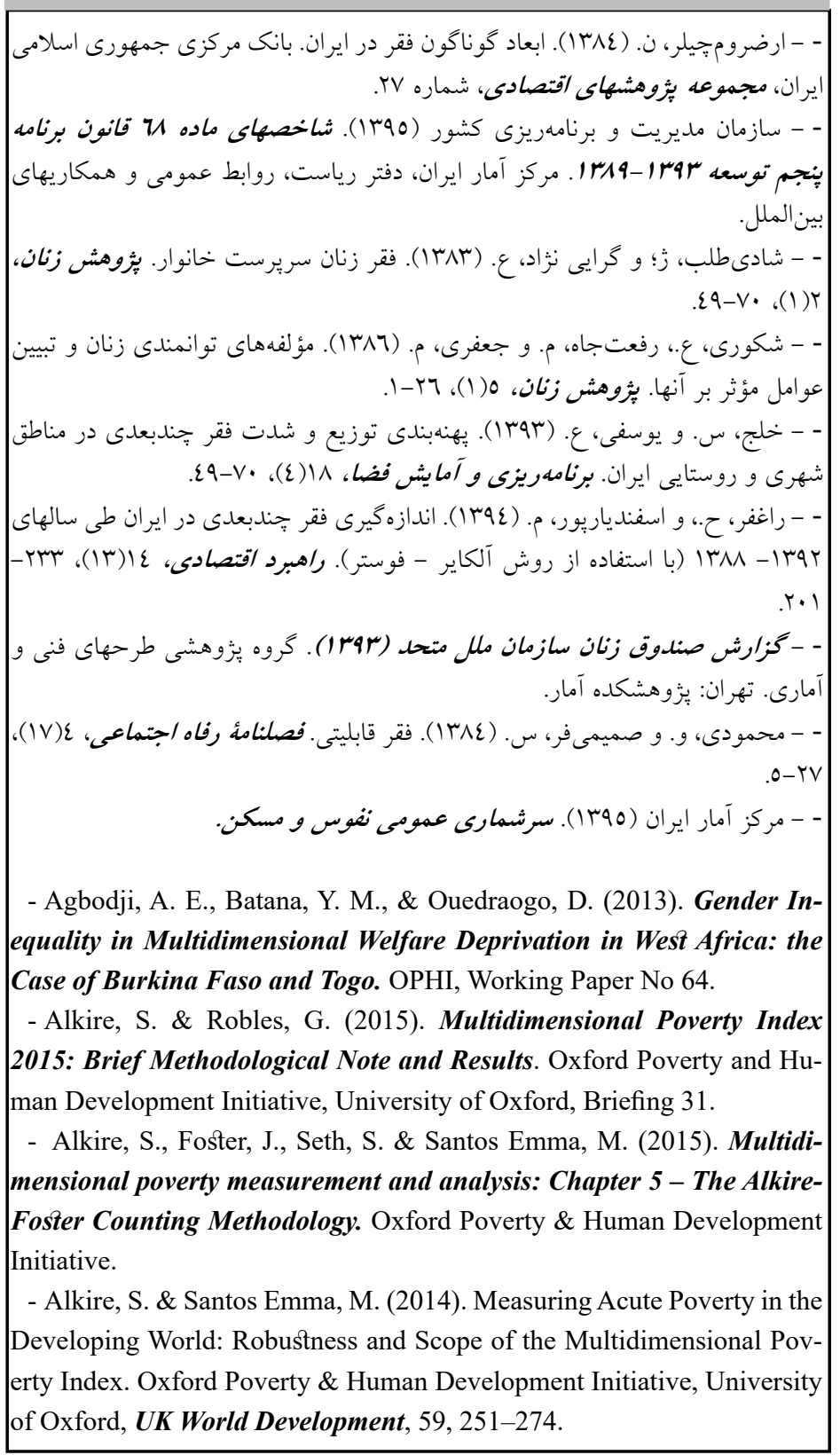


- Alkire, S., Roche, J., Santos Emma, M. \& Seth, S. (2011). Multidimensional Poverty Index 2011: Brief Methodological Note. Oxford Poverty \& Human Development Initiative (OPHI) Oxford Department of International Development Queen Elizabeth House (QEH), University of Oxford.

- Alkire, S. \& Foster, J. (2011). Understandings and Misunderstandings of Multidimensional Poverty Measurement. OPHI WORKING PAPER NO. 43.

- Alkire, S. \& Santos Emma, M. (2010). Acute multidimensional poverty: A new index for developing countries. Oxford Poverty \& Human Development Initiative (OPHI), Working Paper No. 38.

- Alkire, S. \& Foster, J. (2011). Counting and multidimensional poverty measurement. Journal of Public Economics, 95, 476-487.

- Altamirano Montoya, A. J. \& Damiano Teixeira, K. M. (2016). Multidimensional Poverty in Nicaragua: Are Female- Headed Households Better Off?. Social Indicators Research, DOI 10.1007/s11205-0161345-y.

- Batana, Y. M. (2013). Multidimensional measurement of poverty among women in Sub-Saharan Africa. Social Indicators Research, 112(2), 337-362, doi:10.1007/s11205-013-0251-9.

- Chant, S. (2003). Female Household Headship and the Feminisation of Poverty: Facts, Fictions and Forward Strategies. Gender Institute, London School of Economics.

- Fukuda-Parr, S. (January 1999). What does feminization of poverty mean? It isn't just lack of income. Feminist Economics. Taylor and Francis, 5(2), 99-103.

- Pearce, D. (1978). The Feminization of Poverty: Women, Work and welfare. The Urban \& Social Change Review, Special Issue on Women and Work, 11(1-2), 28-36.

- Rogan, M. (2015). Gender and multidimensional poverty in South Africa: Applying the global multidimensional poverty index (MPI). Social Indicators Research, 126(3), 1-20.

- Salazar, R. C. A., Dias, B.Y. \& Pinzon, R. P. (2013). A Counting Multidimensional Poverty Index in Public Policy Context: the Case of Colombia. OPHI, Working Paper, No. 62. 
- Sen, A. (1999). Development as Freedom. New York, Oxford University Press. ISBN 9780198297581. Review in Asia Times.

- Todaro, M. \& Smith, S. (2012). Economic Development., New York University.

- Yu, J. (2013). Multidimensional Poverty in China: Findings based on CHNS. Social Indicators Research, Vol. 112, No. 2, pp. 315-336, doi: 10.1007/s11205-013-0250-x. 